\title{
Assessing North Atlantic right whale health: threats, and development of tools critical for conservation of the species
}

\author{
Michael J. Moore ${ }^{1, *}$, Teresa K. Rowles, Deborah A. Fauquier, Jason D. Baker, \\ Ingrid Biedron, John W. Durban, Philip K. Hamilton, Allison G. Henry, \\ Amy R. Knowlton, William A. McLellan, Carolyn A. Miller ${ }^{1}$, Richard M. Pace III, \\ Heather M. Pettis, Stephen Raverty, Rosalind M. Rolland, Robert S. Schick, \\ Sarah M. Sharp, Cynthia R. Smith, Len Thomas, Julie M. van der Hoop ${ }^{1}$, \\ Michael H. Ziccardi
}

\author{
${ }^{1}$ Woods Hole Oceanographic Institution, Woods Hole MA 02543, USA \\ Co-authors' addresses given in a supplement; www.int-res.com/articles/suppl/d143p205_supp.pdf
}

\begin{abstract}
Whaling has decimated North Atlantic right whales Eubalaena glacialis (NARW) since the $11^{\text {th }}$ century and southern right whales E. australis (SRW) since the $19^{\text {th }}$ century. Today, NARWs are Critically Endangered and decreasing, whereas SRWs are recovering. We review NARW health assessment literature, NARW Consortium databases, and efforts and limitations to monitor individual and species health, survival, and fecundity. Photographs are used to track individual movement and external signs of health such as evidence of vessel and entanglement trauma. Post-mortem examinations establish cause of death and determine organ pathology. Photogrammetry is used to assess growth rates and body condition. Samples of blow, skin, blubber, baleen and feces quantify hormones that provide information on stress, reproduction, and nutrition, identify microbiome changes, and assess evidence of infection. We also discuss models of the population consequences of multiple stressors, including the connection between human activities (e.g. entanglement) and health. Lethal and sublethal vessel and entanglement trauma have been identified as major threats to the species. There is a clear and immediate need for expanding trauma reduction measures. Beyond these major concerns, further study is needed to evaluate the impact of other stressors, such as pathogens, microbiome changes, and algal and industrial toxins, on NARW reproductive success and health.
\end{abstract}

${ }^{*}$ Corresponding author: mmoore@whoi.edu

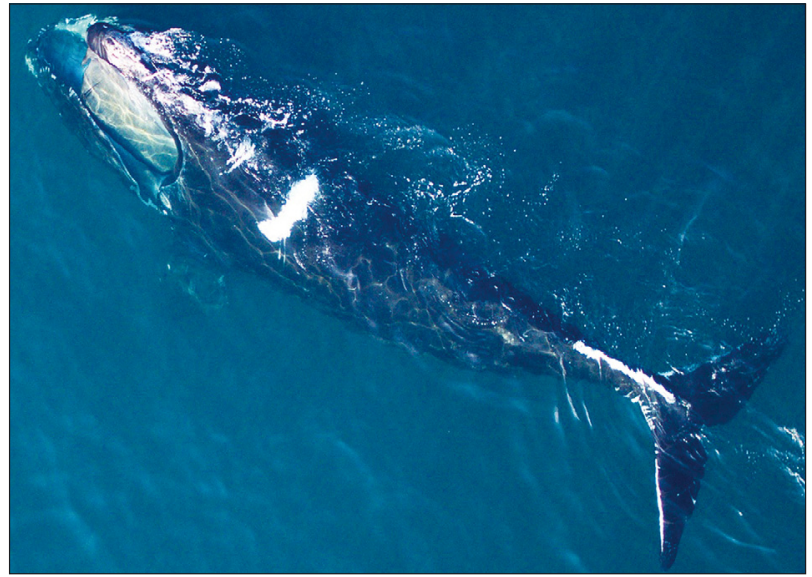

North Atlantic right whale (Catalog \#3530 'Ruffian'), showing healed scarring from an entanglement 8 yr earlier.

Photo: J. Durban \& Holly Fearnbach

Current and new health assessment tools should be developed and used to monitor the effectiveness of management measures and will help determine whether they are sufficient for a substantive species recovery.

KEY WORDS: Right whale $\cdot$ Health · Trauma · Reproduction · Stressor · Cumulative effects

() The authors 2021. Open Access under Creative Commons by Attribution Licence. Use, distribution and reproduction are unrestricted. Authors and original publication must be credited. 


\section{INTRODUCTION}

The North Atlantic right whale (NARW) Eubalaena glacialis species is Critically Endangered and declining. Past and current conservation measures have failed to maintain a recovery trajectory for the species. Therefore, better understanding of the current status of NARW health, and tools to evaluate health, are critical to reverse the decline and restart the recovery of this species. The challenges of studying large whales and their health include, but are not limited to, the following factors: distance-, weatherand season-dependent logistics; locating them; collecting and analyzing the data; and determining the causes of observed morbidity and mortality. A recent review of the right whale genus Eubalaena spp. (Harcourt et al. 2019) summarized the extensive relevant literature in the context of future directions for comparative research among the 3 extant species to inform conservation. Topics included variable recovery from historic whaling, linking individuals to population level response, adapting to shifting resources, emergent diseases and vulnerability under stress, and cumulative effects. Our review summarizes data, publications and past workshops, related to the health of NARWs as discussed at a workshop in Silver Spring, MD, USA, in June 2019 (Fauquier et al. 2020). Previous workshops are summarized in that report (Brownell et al. 1986, Best et al. 2001, Reeves et al. 2001, O'Hara et al. 2003, Rowles et al. 2006, International Whaling Commission 2010, Thomas et al. 2013, Sironi et al. 2018, Sisson \& Long 2018). Additionally, we periodically refer to unpublished analyses of data by authors of this review to provide as current a perspective as possible. Most of those data are available from the NARW Consortium (NARWC) database collection (www.narwc.org/narwc-databases.html).

Implications and recommendations from the 2020 workshop, and consequent discussions, are then presented in the context of (1) furthering our overall understanding of NARW health, and (2) the use of health assessment tools to gauge the efficacy of measures designed to enhance the recovery of the NARW species. For a recent bibliography on this topic see https://repository.library.noaa.gov/view/noaa/20221.

For the purpose of this review, we define wildlife health following Stephen (2014, p. 427)

Health is the result of interacting biologic, social, and environmental determinants that combine to affect the animal's or population's capacity to cope with change. Health cannot be measured solely by what is absent, but rather by characteristics of the animals and their ecosys- tem that affect their vulnerability and resilience. Wildlife health is not a biologic state but rather a dynamic social construct based on human expectations and knowledge.

Following centuries of whaling, with the last documented event in 1967 (Maul \& Sergeant 1977), the NARW species underwent a very slow recovery $\left(\sim 2.8 \% \mathrm{yr}^{-1}\right)$ until 2010 (Fig. 1). Since then, abundance has declined by $20 \%$, so that as of 2020 there are about 356 animals remaining (Pace et al. 2017, NOAA 2020, Pettis et al. 2020). In 2020, the IUCN changed the species listing from Endangered to Critically Endangered (Cooke 2020), the only large whale species in the world to warrant this designation. The North Pacific right whale E. japonica is listed by the IUCN as Endangered, with the Northeast Pacific subpopulation as Critically Endangered. In contrast, most southern right whale (SRW) E. australis populations have recovered remarkably from historic whaling, despite a major setback from Russian whaling in the 1960s (Yablokov 1994, Corkeron et al. 2018). The species is listed as of Least Concern by the IUCN, although in some habitats SRW sightings have plateaued in recent years (Jackson et al. 2020, Stamation et al. 2020).

Right whales are individually identified using photographs of cornified skin patterns, called callosities, on their heads (Payne et al. 1983, Kraus et al. 1986, Kraus 1990). The North Atlantic Right Whale Catalog (http://rwcatalog.neaq.org) contains all known photographed sightings of NARWs from 1935 to the present (Hamilton et al. 2007). The Catalog is used to monitor their distribution, associations, survival, reproduction, movement, and health. There is an intensive photo-identification survey effort conducted annually in many NARW habitats resulting in an average of $75 \%$ of this species being photo-documented each year (Pettis et al. 2020). The Catalog is the hub of the NARWC database collection (www. narwc.org/narwc-databases.html).

A recent broad-scale NARW distribution shift began in 2010 or 2011 (Record et al. 2019). Sightings decreased drastically on the calving ground off the southeastern USA and in 3 northern feeding habitats (Davies et al. 2019, Gowan et al. 2019): Great South Channel (southeast of Cape Cod, MA, USA), Bay of Fundy, and Roseway Basin south of Nova Scotia (Canada). As much as $50 \%$ of this species had been seen in each of these habitats in some years prior to 2010 (Fauquier et al. 2020). Recently, annual counts have decreased to only about 100 individuals on average in the Great South Channel and 35 or fewer in the other 3 habitats (except in 2014 in the Bay of 


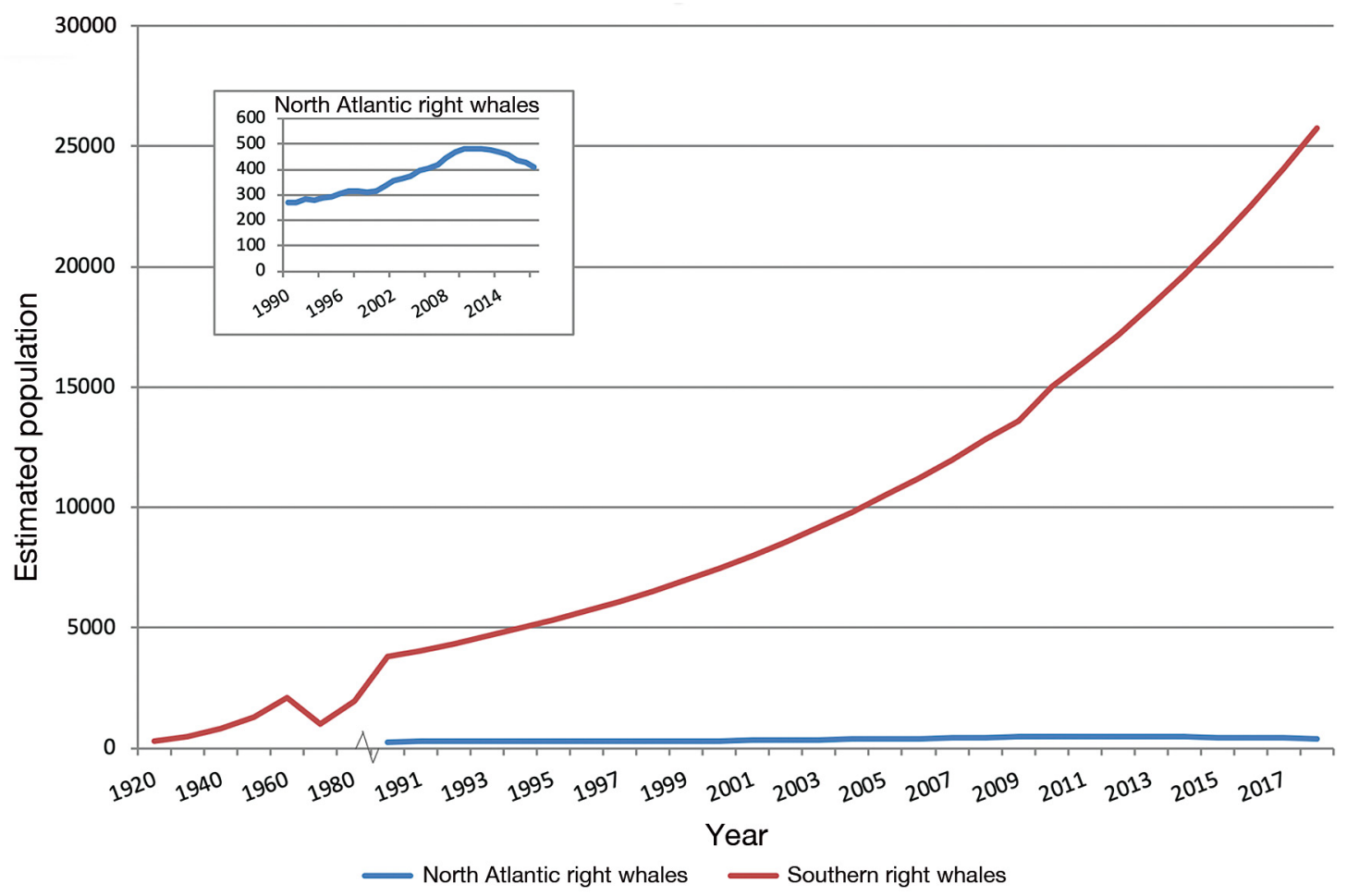

Fig. 1. Population trends in the North Atlantic and southern right whale species (estimates for North Atlantic species prior to 1990 are unavailable; southern estimates prior to 1990 on decadal scale). Illegal whaling caused a downturn in the southern species in the 1960s. Figure modified from Moore \& Myers (2019); used by permission. Data from International Whaling Commission (2013), Pace et al. (2017), Pettis et al. (2020)

Fundy, when over 100 whales were present for a very short time). At the same time, sightings increased in one well-studied habitat, Cape Cod Bay, MA, USA, and in 2 lesser historically known feeding habitats: one south of Nantucket, MA, USA, and one in the Gulf of St. Lawrence, Canada. Since 2010, over 250 whales have been seen annually in the first region, and 100 to 150 have been seen annually in each of the latter two. In addition to sightings, passive acoustic data show an increased occurrence of NARW calls off the mid-Atlantic, herein described as north of Cape Hatteras to south of Cape Cod, and some calls along the edge of the continental shelf (Davis et al. 2017).

These distribution shifts have impacted the collection of sightings and photos and the data derived from those observations. The average percent of whales photographed and identified annually dropped from $81 \%$ during the $8 \mathrm{yr}$ before the shift (2003 to 2010) to $68 \%$ during the $8 \mathrm{yr}$ after the shift (2011 to 2018) (Pettis et al. 2020). This smaller percentage of the species being observed annually impacts the precision and potential accuracy of abundance estimates. The decrease in shipboard photographs, which had been primarily collected from historical high-residency areas (e.g. the Bay of Fundy and off the south- eastern USA in the 2000s) affects the ability to assess body condition and scarring from shipboard images. Finally, mothers are being seen with their calves less frequently on the northern feeding grounds, making it harder to photo-identify those calves because their callosities are generally not well developed until the latter half of their birth year, and at the very least, this has delayed our ability to catalog those calves. These impacts on the photo-identification data collection have downstream effects (e.g. the potential underestimate in abundance and calf survival) that should be considered when analyzing the data and assessing monitoring power especially when comparing pre-2010 to post-2011 derived products (Fauquier et al. 2020).

In summary, cataloging the location and identification of individual NARWs, year by year, has been the cornerstone of our developing understanding of the health of individuals, their movements, and the species as a whole. Therefore, we need to regain adequate cataloging of the species, especially in light of the recent habitat shifts, by increasing photo identification effort in the mid-Atlantic, southern New England, and the Gulf of St Lawrence among other currently important habitat areas. In addition, we need to be better prepared for future 
shifts of distribution and rapidly shifting efforts to maintain adequate photo-identification of the population.

\section{RESULTS}

\subsection{North Atlantic right whale trauma}

\subsubsection{North Atlantic right whale mortality}

There has been little comparison of mortality patterns between SRW and NARW. Such comparisons as there are should be expanded. In Peninsula Valdés, Argentina (a well-studied SRW calving ground with low historical calf mortality) between 2003 and 2018, $20 \%(738 / 4403)$ of calves (mostly neonates) died (Fig. 2) (Sironi et al. 2018). Current theories as to the cause(s) include predation from kelp gull attacks (Sironi et al. 2018). There have been reports of SRW vessel strikes and entanglements (Van Waerebeek et al. 2007, Kemper et al. 2008, Zappes et al. 2013). However, these events have not precluded the species from a substantial post-whaling recovery (Fig. 1). In contrast, for NARW, human-induced trauma has been a major factor in the failure of that species to recover. Their perinatal mortalities are from natural causes, but older calves can be vessel struck, while juveniles and adults die acutely after asphyxiation in heavy fishing gear, or after severe vessel trauma, or chronically after a debilitating entanglement, or initially sublethal vessel trauma. From early Basque whaling through commercial whaling, by the 1930s NARW numbers had been reduced to possibly less than a hundred (Reeves et al. 2007). Incidental

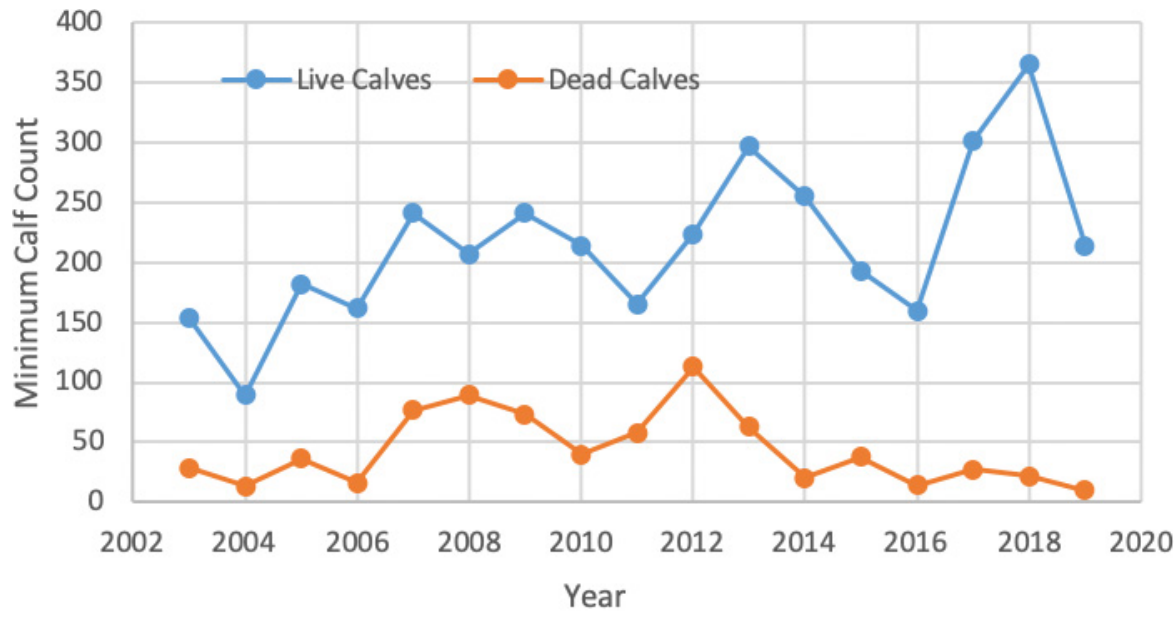

Fig. 2. Minimum counts of live and dead southern right whale calves in Peninsula Valdés, Argentina, 2001-2019. Data: Sironi et al. (2018), M. Sironi, V. Rowntree and M. Uhart pers. comm. mortalities caused by commercial fishing operations and vessel strikes in the past 50 yr have kept the species numbers severely reduced, albeit with a slow recovery until 2010, but with a subsequent decline though 2020 as described above (Pettis et al. 2020). In the late 2010s, clustered mortality events occurred in the Gulf of St. Lawrence with 12 deaths in 2017 and 9 in 2019 - the majority due to human activities (Daoust et al. 2018, Sharp et al. 2019, Bourque et al. 2020). This, along with mortalities in the USA, resulted in its National Marine Fisheries Service (NMFS, part of the National Oceanic and Atmospheric Administration [NOAA]) declaring an Unusual Mortality Event (www.fisheries.noaa.gov/national/marinelife-distress/2017-2020-north-atlantic-right-whaleunusual-mortality-event), a stranding that is unexpected, involves a significant die-off of any marine mammal population, and demands immediate response (16 USC $\S 1421 \mathrm{~h}(6)$; see https://www.fisheries. noaa.gov/national/marine-mammal-protection/ marine-mammal-protection-act).

A review of 54 NARW mortalities from 1970-2002 (Moore et al. 2004), an average of 1.7 (54/32) mortalities per year, found anthropogenic trauma in $77 \%$ (14/18) of juveniles and adults that were completely necropsied. Of these, the cause of death (COD) was determined to be vessel strike in $71 \%(10 / 14)$ while $29 \%$ (4/14) died of entanglement. The COD for the remaining 4 juveniles and adults could not be determined. More recently, Sharp et al. (2019) undertook a thorough review of 70 deaths between 2003 and 2018, an average of 4.7 (70/15) mortalities per year, in which $80 \%(56 / 70)$ of carcasses were examined externally and $63 \%$ (44/70) were necropsied. Where COD was determined, $88 \%$ (38/43) were anthropogenic in origin. The relative threat of entanglement in commercial fishing gear increased from the previous estimate, accounting for $58 \%(22 / 38)$ of the anthropogenic deaths, while vessel strike accounted for $42 \%(16 / 38)$ of these cases. Females accounted for $66 \%$ $(19 / 29)$ of known-sex adult deaths. In both studies (Moore et al. 2004, Sharp et al. 2019), juvenile and adult mortalities of NARWs from known causes were all due to anthropogenic trauma. In the 1980s through the 2000s, deaths were overwhelmingly due to vessel strikes as animals transited either south to the calving grounds or back north to feeding grounds. During this time, necropsy teams documented 3 pregnant NARWs 
with evidence of vessel strikes in the mid-Atlantic and southeast USA, which motivated the development of coast-wide seasonal management areas (SMAs), where most vessels $>65 \mathrm{ft}(\sim 20 \mathrm{~m})$ are required to slow to 10 knots or less at certain times of the year (when NARWs are expected to be present) as a conservation strategy (Silber et al. 2014).

Diagnostic necropsies provide critical data, for maintaining an up-to-date understanding of how anthropogenic trauma on the species is changing in time and space. Without these data, the necessary ongoing optimization and evaluation of mitigation measures cannot occur.

\subsubsection{Visual health and injury assessments}

Assessment of live animals in the context of their catalogued individual identity gives a unique, sequential perspective on the status and trend of each animal and aids in identifying sublethal impacts that may affect reproductive success and therefore be targets for mitigation. The visual health assessment (VHA) method (Pettis et al. 2004, Rolland et al. 2016) allows for non-invasive assessments of NARW health using photographs taken from boats and aircraft. Data on body condition, skin condition (lesions and skin sloughing), rake marks (shallow striations in the skin) forward of the blowholes, and cyamids (whale lice) around the blowholes can be linked to the NARW Catalog (http://rwcatalog.neaq.org), allowing one to examine associations between health, individual life-history, and post-mortem information (www.narwc.org/narwc-databases.html). Analyses of these data have established connections between health, reproduction, and anthropogenic impacts (Pettis et al. 2004, Rolland et al. 2016). Two health conditions, emaciated body condition and swath skin lesions, have emerged as prognostic indicators of poor NARW survival (Pettis et al. 2004, Hamilton \& Marx 2005). The incidence of these conditions has varied over time, with the highest incidence of both documented in 2011-2016 (Pettis 2019). Other types of skin lesions are regularly observed on NARW, though the etiology, and their impact on survival and reproduction are unknown (Pettis et al. 2004, Hamilton \& Marx 2005, Rolland et al. 2016). Beginning in 2009, far more whales have been scored as thin, at least once annually, than the number scored with poor skin condition (Pettis et al. 2004). The VHA method has been valuable in retrospective analysis for evaluating sub-lethal anthropogenic injury impact on health, informing annual injury determinations and estimates of human impact on this species, and predicting survival (Pettis et al. 2004, Schick et al. 2013). Additionally, VHAs show promise in helping to estimate the time of death when whales are not sighted post injury (H. M. Pettis unpubl. data).

The VHA method has also enabled a broad, longterm assessment of the nature and impact of sublethal trauma on the species. Qualitatively, its applicability to the entire photo-ID catalog has made it a vital resource, given its sample size, and it should continue to be promulgated to adequately monitor the extent and variation in sub-lethal trauma impacts on the species. Quantitively it has been linked to demographic outcomes (Schick et al. 2016).

\subsubsection{NOAA fisheries serious injury assessments}

In the USA, NMFS is responsible for management of NARWs under the Endangered Species Act and Marine Mammal Protection Act (MMPA). As mandated by the MMPA, it estimates the number of human-caused mortalities and serious injuries of NARWs. Predicting the likely outcome for animals with substantive injuries is important to estimate the overall mortality incidence. Furthermore, recent modeling (Pace et al. 2021) has shown that only $38 \%$ of total mortality was detected during $1990-2017$ : this cryptic mortality factor is driven at least in part by NARW lost to follow up because they are emaciated and sink due to being negatively buoyant (Moore et al. 2020). Others will likely float offshore until they decompose, without ever being observed, or at least not reported. The extent of the crypsis was modeled by comparing the number of carcasses documented to the number of animals that disappeared from the photo-ID catalog through time. A formal method to assess the status of chronically traumatized individual NARWs, linked with an ongoing estimate of cryptic mortality, is critical to understanding their prognosis and overall mortality incidence.

NMFS serious injury (SI) assessments estimate annual rates of human-caused mortality and SI for all marine mammal stocks occurring within USA waters (NOAA 2012, 2020). NMFS Northeast Fisheries Science Center (NEFSC) has made SI determinations for western North Atlantic large whale stocks since 1999 using all available relevant injury event information including sighting history, necropsy reports, and health assessments when available. NEFSC used its own criteria to assess large whale injuries until 2012, when USA National SI criteria guidelines were 
established (NOAA 2012). NEFSC criteria used prior to 2012 did not count events for which there were insufficient data to make a lethal take determination against potential biological removal (PBR). A take is defined by the MMPA as 'to harass, hunt, capture, or kill, or attempt to harass, hunt, capture, or kill any marine mammal' (16 USC § 1362 (16)). PBR is defined by the MMPA as the maximum number of animals, not including natural mortalities, that may be removed from a marine mammal stock while allowing that stock to reach or maintain its optimum sustainable population. The National criteria now address such data-poor events by providing prorated values that count against PBR. A retrospective application of the National criteria to all NARW injury events from 2000 to present resulted in only $0.8 \%$ (14/184) events between 2000 and 2011 being changed from a 0 to a prorated value, which illustrates that injury determinations of this stock have been relatively consistent across the years despite evolving SI criteria (Fig. 3) and is likely due to the data-rich nature of NARW injury events. As seen in Fig. 3, and further supported by others (Knowlton et al. 2016), the rate of entanglement related SI and mortality has been increasing in the last decade, whereas that of vessel strike has decreased. The entanglement rate alone has remained above PBR throughout the timeline (i.e. since 2000). If it were not for disentanglement efforts, the situation would be even worse, as in some circumstances, disentan-

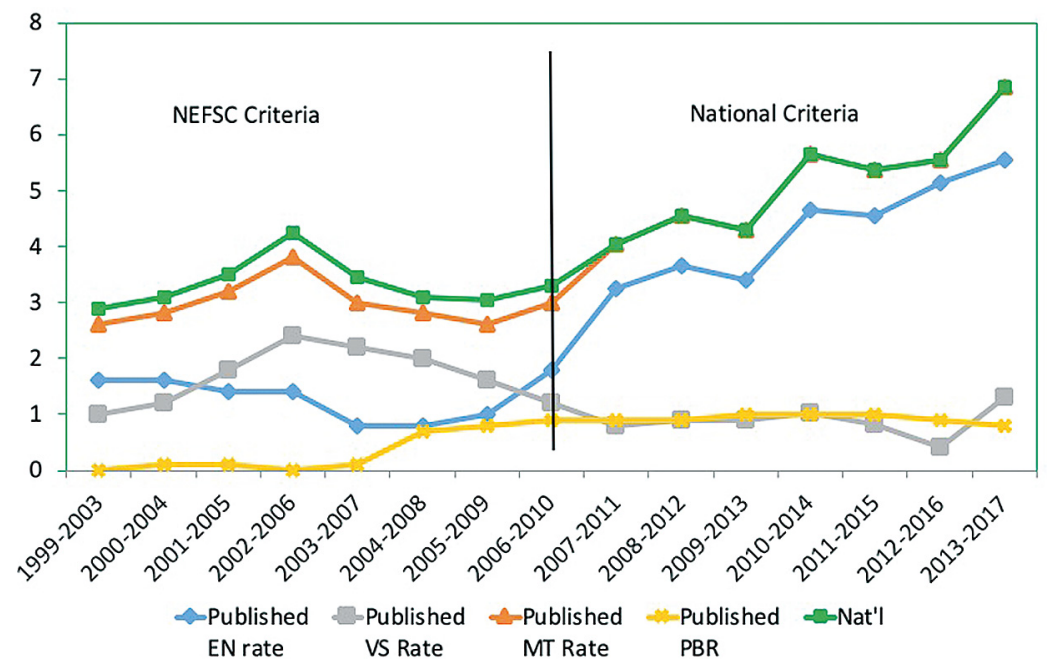

Fig. 3. Rolling 5 yr average of (USA and Canada) North Atlantic right whales (NARW) entanglement (EN), vessel strike (VS), total mortality (MT), and serious injury (SI, excluding 27 cases prevented by disentanglement), and potential biological removal (PBR). Northeast Fisheries Science Center (NEFSC) criteria were applied up to 2010. National (Nat'l) SI criteria were applied after 2010, and retroactively to earlier years, showing the minor difference between the 2 criteria glement teams are able to avert SIs. However, the practice of not counting such cases towards PBR does devalue such data as an index of entanglement risk.

The SI determination process is the primary tool used by NMFS to include an estimate of the annual human-caused mortality and serious injury in annual stock assessment in the USA. It provides an annual update on the nature and extent of the different sources of lethal trauma to the species. A major limitation is the lag time from when data are available to when they are incorporated into a publicly available annual report. Given the current high incidence of serious injuries and mortalities, a closer to real-time analysis, and reporting, would facilitate equally prompt trauma mitigation enhancement.

\subsubsection{Frequency, and effects, of vessel strikes and entanglement on North Atlantic right whale reproduction}

During times of decadal prey declines, calving output is lower (Hlista et al. 2009, Meyer-Gutbrod et al. 2015). Additionally, quantifying the sublethal incidences of vessel and rope trauma on NARW reproductive success, in the context of their unfolding demographic and migratory history, is a critical aspect of understanding these sources of trauma. As part of the recent workshop, we updated earlier studies of vessel and rope trauma.

2.1.4.1. Vessel strikes. We examined NARW Catalog photographs of live individuals for evidence of external trauma from vessel strikes (propeller cuts or gashes) and necropsy reports for cause of death information. External sharp trauma wounds on both live and dead whales resulting from vessel strike were categorized as superficial, shallow, or deep, while blunt trauma cases were only determined from necropsy reports (Fig. 4). With the implementation of a USA ship-speed rule in 2008, there appeared to be some reduction in lethal vessel strikes for NARWs when comparing known vessel-struck carcass detections in or within 45 nmiles $(74 \mathrm{~km})$ of an active SMA pre- and post-rule, whereas for humpback whales Megaptera novaeangliae mortalities were 


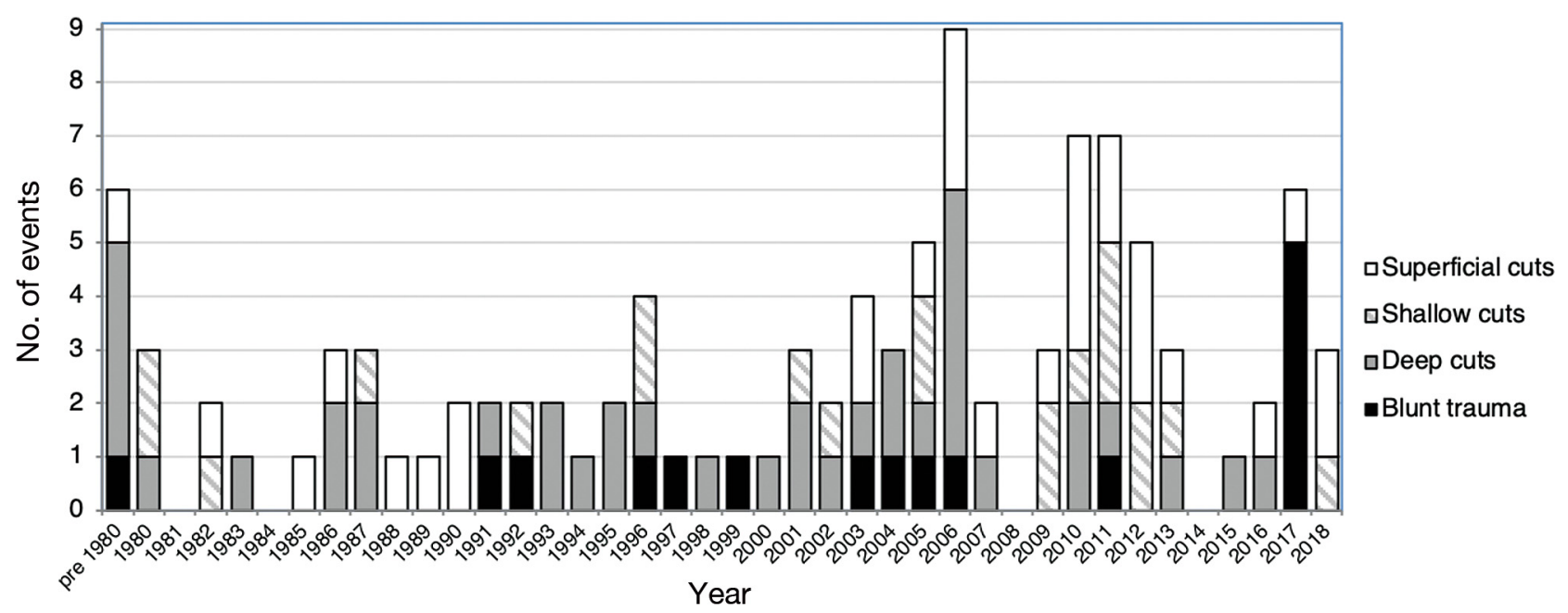

Fig. 4. Incidence of blunt trauma, and 3 degrees of severity of propeller cuts observed in 101 North Atlantic right whales. Of animals with cuts, 8 were found dead and 66 alive, but 7 of the latter were later presumed dead as a result. The 16 blunt trauma cases were all dead. Thus, a total of 29 were known or presumed dead from vessel strike (A. Knowlton et al. unpubl. data.)

reduced both inside and outside the areas (Laist et al. 2014) (Table 1). Meanwhile, van der Hoop et al. (2014) found no detectable reduction in vessel strike mortalities of all large whale species in the actual SMAs along the eastern USA, suggesting that the existing SMAs may not be large enough to provide adequate protection. Furthermore, in recent years right whales have ventured further into Canadian waters, with a shift into the Gulf of St. Lawrence, where no protection measures were in place until after at least onethird of the 12 mortalities in the region were reported as vessel strike in 2017 (Fig. 3; Daoust et al. 2018, Sharp et al. 2019). Two others of the 12 were acute entanglements, and 6 could not be diagnosed.

A recent assessment of fate by propeller wound category revealed that superficial and shallow cuts did not affect 3 yr survival, but deep cuts were lethal in the majority of cases (A. R. Knowlton \& A. M. Costidis unpubl. data). A detailed, quantitative assessment of propeller cuts, carried out for 39 cases, showed that vessels $>65 \mathrm{ft}(\sim 20 \mathrm{~m})$ were involved in most of the deep cut cases, although there were 2 cases involving vessels in the 40-65 ft $(12-20 \mathrm{~m})$ length range that resulted in deep cuts and subsequent fatality (A. R. Knowlton \& A. M. Costidis unpubl. data).

2.1.4.2. Entanglements. For entanglements, a total of 1538 interactions have been documented between 1980 and 2017 involving $86.1 \%(642 / 746)$ of the species; $8 \%(51 / 642)$ of these cases involved attached gear (Knowlton et al. 2012, A. R. Knowlton unpubl. data). Some whales have evidence of as many as 8 entanglement interactions over the course of a lifetime. Incidents of moderate and severe entanglements have become more prevalent in the last decade (Knowlton et al. 2016). These are known to cause health impacts and reduced survival, especially in reproductive females (Fauquier et al. 2020). The complexity of attached gear has also been assessed, and the majority of entanglements since the mid-1990s has been deemed high-risk, i.e. likely to be lethal without intervention, possibly because of increasing rope strengths, resulting from manufacturing changes (Knowlton et al. 2016). Based on these results, Knowlton et al. (2016) suggested maximum rope strengths of $1700 \mathrm{lb}(\sim 773 \mathrm{~kg})$ for consideration in fixed fishing gear throughout the NARW range in order to allow more whales to break free from entanglements.

2.1.4.3. Impacts of human activities on reproductive females. An assessment of all reproductive females (i.e. females that have had a calf) since 1980 found that $42 \%(76 / 180)$ have either been found

Table 1. Vessel-struck North Atlantic right/ humpback whale deaths inside or within 45 nmiles $(74 \mathrm{~km})$ of seasonal management areas (SMA) versus those beyond 45 nmiles, before and after the SMA implementation on December 8 , 2008 (Laist et al. 2014)

\begin{tabular}{|c|c|c|c|c|}
\hline & \multicolumn{2}{|c|}{$\begin{array}{l}\text { Inside or }<45 \text { nmiles of } \\
\text { SMA boundary }\end{array}$} & \multicolumn{2}{|c|}{$\begin{array}{l}\text { Beyond } 45 \text { nmiles of } \\
\text { SMA boundary }\end{array}$} \\
\hline & Right & Humpback & Right & Humpback \\
\hline 1990 to Dec 82008 & 13 & 12 & 2 & 14 \\
\hline Dec 92008 to Dec 82013 & 0 & 2 & 2 & 4 \\
\hline
\end{tabular}


dead or have disappeared, with at least one-third of those losses due to vessel strikes and entanglements. The effect of entanglement injury severity on fecundity indicates a cessation in calving for a period of time after a severe injury (van der Hoop et al. 2017a, A. R. Knowlton unpubl. data).

Both vessel strikes and entanglement continue to impact right whale reproductive success. Thus, to enable species recovery, reduction in mortalities have to be accompanied by substantial reduction of sub-lethal trauma as well.

\subsubsection{Trends in growth and body condition from photogrammetry}

Orthogonal aerial photogrammetry with accurate altitude data (Durban et al. 2016) can provide precise measurement of large whale length and width, enabling analysis of energy transfer during suckling (Christiansen et al. 2018). High-resolution drone images also provide information on skin condition, whale lice burdens, and the severity/incidence of entanglement wounds, notably coupled with quantitative photogrammetry measurements from the same whales.

Comparison between SRWs in Argentina, New Zealand, and Australia to NARWs in the North Atlantic revealed NARW juveniles, adults, and lactating females to be in generally poorer body condition and to be attaining shorter adult lengths than SRW (Fig. 5; Christiansen et al. 2020). Aerial photogrammetry studies to assess trends in growth and body condition of NARWs in Cape Cod Bay, MA, in March and April 2016-2020 (J. W. Durban unpubl. data) are being compared with aerial images collected by NOAA's Southwest Fisheries Science Center (SWFSC) during August 2000-2002 using manned aircraft flying over the Bay of Fundy. For both datasets, matching whales to the NARW Catalog enables body length, and width profiles, to be linked to whale age, sex, and life histories, and assessment of changes in an individual whale's condition over time. Ongoing analysis of the NARW time series (J. W. Durban unpubl. data) revealed some whales are growing more slowly in recent years compared to those growing during the 2000-2002 sampling, as inferred from reduced length at age relationships in the more recent surveys. Whales also appeared to be in poorer body condition in recent spring surveys compared to previous sampling, although the previous study took place in summer, so that change may be due to seasonal change in body condition of this capital breeder. Ongoing longitudinal monitoring during consistent spring sampling in Cape Cod Bay is being used to assess this.

\subsubsection{Energetic cost of entanglement}

NARW recovery is dependent on sustained reproductive success, which requires adequate body condition. Normal energy costs include metabolism, migration, foraging, and pregnancy; additional exogenous stress adds to those costs. Chronically entangled NARWs may carry fishing gear for months to years, and often show signs of considerable loss in energy reserves over that time period, as evidenced by emaciation. Drag measured from gear that was removed from entangled NARWs (van der Hoop et al. 2013, 2016) was combined with other measured parameters, allowing estimation of drag on new entanglement cases at the time of their observation (van der Hoop et al. 2017a). Drag measurements enabled estimation of the energetic cost of entanglement using biomechanics and physical models, and blubber thickness and body condition measurements (van der Hoop et al. 2017b). Impacts of entanglements persist even after disentanglement due to time needed for recovery (van der Hoop et al. 2017a). For the cases evaluated in these studies, the median energetic recovery is 1.3-3 mo (max. $16 \mathrm{mo}$ ).

The role of sub-lethal entanglement drag in reducing NARW health and fecundity should be a major consideration in comparing the efficacy of potential mitigation measures. Thus, while $1700 \mathrm{lb}$ ( 773 kg) breaking strength rope may reduce mortality and sever injury, it will continue to be a source of morbidity. Ultimately, removal of rope from the water column will better enable species recovery.

\subsubsection{Acoustic trauma}

Parks et al. (2007) showed that right whales call at a higher frequency, and at a lower rate, in higher noise conditions, perhaps as a response to increased background noise. This may increase communication range under such conditions (Tennessen \& Parks 2016). The resultant health impacts of acoustic stressors are unclear (Rolland et al. 2012). Better understanding of the effects of background shipping and offshore wind energy production noise and episodic noise associated with seismic survey and windfarm installation are critical in terms of focused mitigation. 

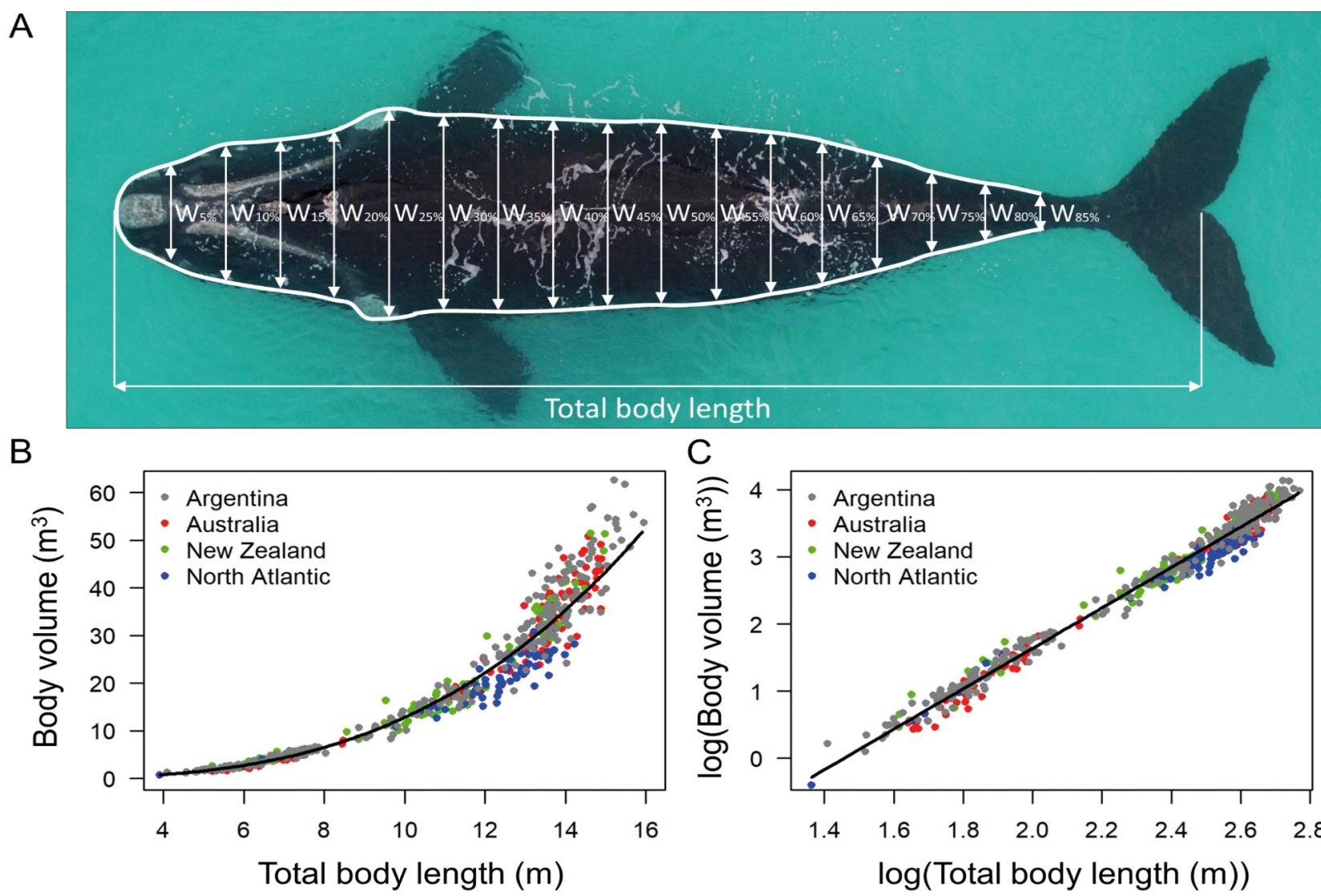

B

Fig. 5 . Body condition compared between southern right whales in New Zealand, Australia and Argentina, and North Atlantic right whales. Solid line represents the back-transformed fitted values of the linear model (reproduced from Christiansen et al. 2020; used by permission)

\subsection{Reproduction in North Atlantic right whales}

\subsubsection{Reproductive success}

NARW had one-third the calving success of SRW between 1992 and 2016 (Corkeron et al. 2018). Nutrition is a major determinant of reproductive success. In a study of SRW calving success in southern Brazil, significant correlations were found with krill densities, Oceanic Niño Index, and Antarctic sea ice area (Seyboth et al. 2016). Similarly, calving success in Argentina was tied to global climate signals (Leaper et al. 2006). A comparison of blubber thickness in SRW and NARW suggested that marked fluctuations in North Atlantic right whale reproduction have a nutritional component (Miller et al. 2011). However, right whale feeding success is dependent on fine-scale plankton densities that do, or do not, elicit feeding (Pershing et al. 2009). Hypotheses concerning NARW migration and foraging strategies have recently been reviewed (Kenney et al. 2020). Plourde et al. (2019) describe foraging areas for NARW in Canadian waters in the context of climate change and the documented
C

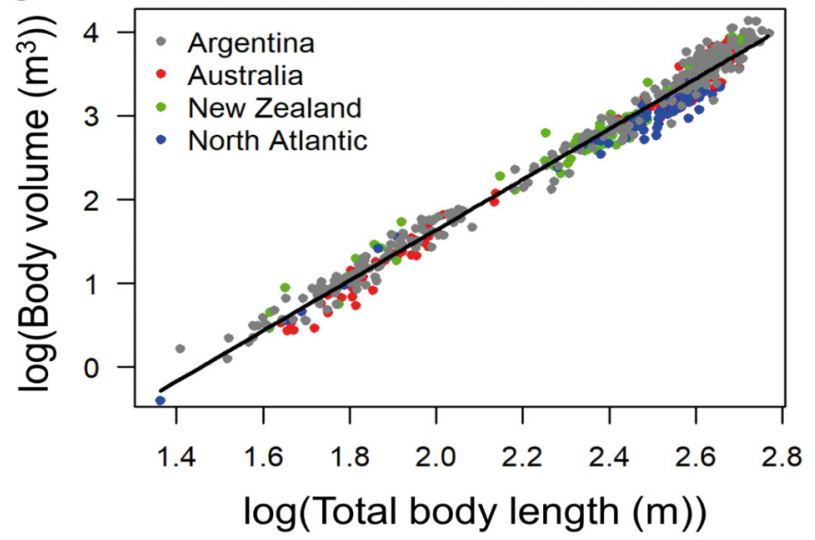


The inter-birth interval, which averaged $3.9 \mathrm{yr}$ 2003-2010, increased to an average of $5.8 \mathrm{yr}$ from 2011-2018, with a peak of 10.2 yr in 2017 (Pettis et al. 2020). The mean age of first parturition (Knowlton et al. 1994, Hamilton et al. 1998) for all known-age females is $10.2 \mathrm{yr}(\mathrm{n}=76$, range 5 to 23 , $\mathrm{SD} 3.3)$. This analysis does not account for potential missed first calving events. The tail of the distribution includes 2 records over $19 \mathrm{yr}$ of age: a first calving at 21 and $23 \mathrm{yr}$, both of which could be the result of missed calving events. However, the mean age of first parturition will likely increase in the future, as half of the known age females between 10 and 19 yr old have not yet been observed with a calf. The combination of the changes in inter-birth interval and age to first reproduction suggests that both parous and nulliparous females are experiencing delays in calving. It remains unknown how many of the current nulliparous 10 to $19 \mathrm{yr}$ old females are biologically able to get pregnant and successfully reproduce. The timing of these calving delays corresponds with the recent distribution shifts described earlier, and those shifts may correlate with changing environmental conditions. Potential explanations for this reproductive cessation or delay are explored under other sections of this review, such as 2.2.2.

The low reproductive rate of NARWs is likely the result of several factors. Forty-nine females calved only once, and $53 \%$ (26/49) disappeared from the sighting record within $2 \mathrm{yr}$ of that calving and very likely did not survive long enough to reproduce again. The remaining $47 \%(23 / 49)$ were seen 3 or more years after their first calving and thus were theoretically available to calve again. Ten percent (6/60) of females over $19 \mathrm{yr}$ old have never calved. Given the age of first parturition presented above, it is unlikely these females will ever calve successfully. That percentage increases to $33.8 \%(46 / 136)$ if the 10 to 19 yr old nulliparous females are included, but these females may just be delaying calving and thus will likely enter the reproductive pool in the future. Another concern is evidence of low calf survival in some females. One female has been able to reproduce, but her calf survival is consistently low. She has had 6 calves, but the last 4 have not survived; at least 2 of them because they were apparently not successfully nursed (www.narwc.org/narwc-databases.html).

Other factors affecting reproductive success include changes in investment in offspring, differences in reproduction in relation to feeding habitats, and changes in NARW social interactions. Hamilton \& Cooper (2010) showed that $71 \%(12 / 17)$ of all calves born in 2001 stayed with their mothers into the sec- ond year. They compared the fitness (age at first breeding and calving rate) of the 2001-born female calves that stayed with their mothers into the second year with those that did not and found no clear difference. In the late 1990s, some females that had a profile of being seen less frequently, which may indicate they fed in unknown habitats, continued to calve when other females stopped. All of the females that calved between 1998 and 2000 fit this profile. For the recent calving downturn, while $60 \%$ of the females in 2017 fit this profile, all of them had prolonged calving intervals equivalent to those of other females that calved during this time suggesting that, although they were calving, they were faring no better than the other females. Investigating these females that may feed elsewhere is hampered by the lack of a consistent or rigorous way to define and categorize them. Finally, the percent of sightings involved in surfaceactive groups appears to mirror the number of calves born (www.narwc.org/narwc-databases.html). This preliminary result could be explored by habitat to see whether the occurrence of these groups, some of which are related to mating, can be correlated with species-wide health. Reversing the trend of failed reproduction, by reducing sub-lethal trauma stands alongside reducing mortality as the 2 critical goals for enabling NARW species recovery.

\subsubsection{Reproductive and stress hormones}

Endocrine studies involving NARWs started in 1999 with the validation of immunoassays to measure steroid reproductive and stress hormone metabolites in fecal samples. Currently, immunoassays for a panel of 6 hormone classes including estrogen, progesterone, androgens, glucocorticoids, aldosterone, and thyroid hormones have been validated (Rolland et al. 2005, Hunt et al. 2006, Burgess et al. 2017, R. M. Rolland unpubl. data) for multiple biological matrices including the following: feces, blubber, blow (exhaled breath), and baleen (Rolland \& Moore 2018). The temporal signature of hormones differs between these matrices from real-time or near-real-time (serum, blow), to days or months (feces and blubber), to years (baleen). Hormone measures from feces, and blubber integrate circulating levels of hormones over these different temporal scales and are especially valuable for assessment of chronic stress.

Over 400 fecal samples collected from 1999-2019 have been assayed for the 6 hormone classes mentioned above. Approximately one-third of the samples have been linked to identified NARWs with 
known life-history data. Results show that concentrations of fecal estrogens, progesterone, and androgens are reliable predictors of sex, pregnancy, and lactation in females and sexual maturity in males (Rolland et al. 2005). Three cases of pregnancy loss or undetected perinatal or young calf death have been inferred using highly elevated fecal progesterone metabolites and sighting records on the calving ground during the following winter, without a calf (R. M. Rolland unpubl. data). Levels of adrenal stress hormone metabolites vary with reproductive status, sex, and physiological state, and reflect relative adrenal cortical activity (Rolland et al. 2017). Comparison of fecal glucocorticoids (FGCs) in healthy NARWs, to those killed acutely (vessel strike), suffering long-term entanglement, or prolonged live stranding (chronic), found extreme elevations of FGCs in cases of severe, chronic illness or injury (Rolland et al. 2017). FGCs have been used to link shipping noise exposure in NARWs to elevated FGCs indicating chronic stress (Rolland et al. 2012). Fecal aldosterone levels provide an additional measure of adrenal cortical activation (Burgess et al. 2017). Fecal thyroid hormones are a biomarker of nutritional status in NARWs, as thyroid gland hormone concentrations decrease during seasonal nutritional deficits and increases during periods of energy abundance (R. M. Rolland unpubl. data).

Studies of chemical profiles in NARW baleen have shown a valuable timeline of data ranging from very recent levels at the gum line, to up to 8 yr prior at the tip (Hunt et al. 2016). In fact, baleen progesterone profiles from 2 NARWs showed elevations 2 orders of magnitude higher than baseline in time points corresponding to known pregnancies. Baleen from a chronically entangled NARW was analyzed for steroid and thyroid hormones and stable isotopes and showed an $8 \mathrm{yr}$ profile of foraging and migration behavior, stress response, and reproduction, with a 23 mo progesterone peak correlating to a single known calving event and elevated triiodothyronine (T3) and thyroxine (T4), suggesting that the entanglement event began 3 mo before it was first sighted entangled (Lysiak et al. 2018). Reproductive and stress hormone studies can usefully continue to investigate the parameters impacting pregnancy and recruitment.

\subsection{Biotoxins and parasites}

A 6 yr (2001-2006) analysis of fecal samples collected in the Bay of Fundy showed that some NARWs were exposed to at least 2 classes of algal biotoxins: paralytic shellfish poisoning toxins (PSP), primarily saxitoxins and amnesiac shellfish poisoning, and domoic acid (DA) (Doucette et al. 2012). In this study, $73 \%(96 / 132)$ of samples tested positive for PSP toxins and $25 \%(31 / 126)$ tested positive for DA. Both biotoxins were also detected in a small number of fecal samples collected in Cape Cod Bay, the Great South Channel and Roseway Basin. The results of this study suggest that NARWs are exposed to both algal biotoxins on an approximately annual basis in multiple habitats for periods of up to 6 mo (April through September). There were similar exposure rates for females and males (PSP: $\sim 70-80 \%$; DA: $\sim 25-30 \%$ ). Both pregnant and lactating females were exposed to both biotoxins, suggesting the potential for maternal toxin transfer and possible effects on fetal and suckling animals. Additionally, $22 \%$ of the fecal samples tested for PSP and DA showed concurrent exposure to both neurotoxins, leading to questions of interactive effects (Doucette et al. 2012). While exposure to these biotoxins was not significantly linked with observed health effects in NARWs (and their sensitivity to these toxins remains unknown), there is a potential for indirect effects (e.g. increased susceptibility to anthropogenic risks: Doucette et al. 2012 discuss possible effects of PSP on whales: neurotoxic effects impacting organ function, diving reflex and effects of DA on reproduction - based on California sea lion research) that will likely never be measurable. These data provide baseline levels of these 2 biotoxins for comparison to exposure levels in the future. A study of the possible role of biotoxins in the calf mortality event in Peninsula Valdés, Argentina, found a relationship between Pseudo-nitzschia spp. densities (but not Alexandrium tamarense) and calf deaths (Wilson et al. 2016).

A 5 yr study (2002-2006) assessed the prevalence of Giardia and Cryptosporidium spp. using analysis of fecal samples (Hughes-Hanks et al. 2005, Rolland et al. 2007, R. M. Rolland unpubl. data). Fecal samples were examined for the presence of cysts/oocysts using an immunofluorescent assay procedure. The overall annual prevalence of Giardia was $68 \%$ $(78 / 115)$ (range $=38-77 \%)$, Cryptosporidium oocysts were detected in $14 \%(16 / 115)$ of samples (range = 7-38\%), and all Cryptosporidium positive samples were co-infected with Giardia. Molecular characterization and phylogenetic analysis of the NARW isolates were unsuccessful, so species and genotypes remain unknown. While the effects of these organisms on NARWs are generally unknown, co-infection with both Giardia and Cryptosporidium was found to be associated with a decline in body condition using 
a visual assessment method (R. M. Rolland unpubl. data).

Thus, SRW and NARW are clearly exposed to a variety of biotoxins and parasites, but their role in health determination remain unclear. Comparative biotoxin studies between SRW and NARW could be of value.

\subsection{Modeling}

2.4.1. Survival assessments and trends with emphasis on reproductive females

Mathematical modeling can be used to link the intermittent spatially referenced observations of individual NARWs and their visual health measurements to estimates of their movement between regions, underlying health, and survival. Such a model, based on a hierarchical Bayesian state-space modeling framework, was constructed using monthly time steps and 9 geographic regions and fitted to over $30 \mathrm{yr}$ of sightings data (Schick et al. 2013, Rolland et al. 2016, Schick et al. 2016). An investigation found negative health impacts in NARWs entangled in gear. Individual's health declined between the date seen without injuries and the first date of entanglement detection, and the overall average health continued to decline for those whales with attached gear. Results were further parsed by entanglement severity and category, by presence/absence of gear, by sex, and, for females, by reproductive class (A. R. Knowlton unpubl. data). These declines in health were greater among whales categorized as having severe entanglements, both with and without gear present. The average health score during entangled periods was poorer for reproductively active females, with declines in health translating to lower reproductive output. Survival analysis as a function of sex and entanglement severity showed that severe injuries resulted in steep declines in individual survival, with the decline in survival being greater for females than for males.

The above model was built and fit to data (as well as incorporating expert opinion) pre-2011, before the documented shift in distribution; the model is currently being altered to account for the changing movement patterns and VHA data. The spatial portion of the model needs to be updated to accurately depict recent movement patterns into previously understudied regions, as well as to account for the changing VHA data collection platforms. The sightings model from (Schick et al. 2013) is (1) individual specific, but not time varying, and (2) indexed to sur- vey effort in different regions. This component of the model needs to be updated in order to better account for recent changes in effort, and distribution.

\subsubsection{Population models and assessment tool}

A NARW population evaluation tool is under development, with objectives that include prospective estimates of extinction risk and other demographic characterizations over various time scales. The model will consist of a baseline scenario projection and a quantitative threat assessment to examine the effects of modifying projected threat influences on demographic processes (i.e. scenarios modified from baseline). Although the lethal impacts of threats are relatively straightforward to include in a population viability model, the non-lethal influence of entanglement wounding, vessel-collision wounding, anthropogenic noise, changes in prey distribution and quality, and contaminants on body condition, growth, reproduction and survival are more difficult to parameterize. Model projections that include influences of all threats are required, even while the functional relationships between threat and health outcomes are not well-known. The more these relationships can be bounded by expert opinion, the less uncertainty will be transferred into population projections.

Modeling survival and population assessment are important activities to inform managers of NARW status and trends. Further understanding of the interactions of multiple stressors and their impacts on mortality and morbidity will enhance ongoing management.

\subsection{Emerging tools}

\subsubsection{Baleen whale microbiomes as potential indicators of health}

In humans, microbiotas (assemblages of microorganisms) are linked to many aspects of health, such as body condition, digestion and nutrition, immune function, inflammation, and behavior (Ley 2010, Cho \& Blaser 2012, Ezenwa et al. 2012, McFall-Ngai et al. 2013). Although microbiotas of marine mammals are not as well studied as those of humans, there is evidence of highly diverse skin, respiratory, gut and oral microbiomes that vary with host phylogeny, diet, habitat, and health (Apprill et al. 2014, 2020, Nelson et al. 2015, Sanders et al. 2015, Bik et al. 2016). Little is known about the microbiotas of right whales, but 
results from studies on the skin, blow, and gut microbiotas of other baleen whale species support a framework for using the microbiotas of these sample types to monitor baleen whale health, including that of right whales.

Blow and skin microbiotas of humpback whales from different geographical locations have been investigated by a few studies using high-throughput sequencing of the $\mathrm{V} 4$ region of the small subunit ribosomal RNA (16S rRNA) gene. In one study evaluating blow collected from seemingly healthy humpback whales (Apprill et al. 2017), 25 bacteria were found to be common to all samples - one of the most extensive core microbiotas found in any mammal to date. Similar results and sequences were also recovered in blow collected from southern hemisphere humpback whales (Pirotta et al. 2017). Apprill et al. (2017) also detected numerous genus-level relatives of mammalian pathogenic bacteria. Because the whales appeared healthy, these pathogen relatives likely were not acting as pathogens at the time, but such screening methods could be used to quickly identify samples that need to be examined for pathogens with finer resolution methods. Similar to the trends for core bacteria in the blow samples, 2 skinassociated bacterial taxa were common to seemingly healthy humpback whales from different oceans (Apprill et al. 2014, Bierlich et al. 2018), where abundances appeared to be affected by environmental conditions (Bierlich et al. 2018). Additionally, altered skin microbiotas were observed in a handful of humpback whales with compromised health (stranded, entangled) (Apprill et al. 2011, 2014). Taken together, these results suggest that screening for changes to the signatures of the skin and blow microbiotas, i.e. the presence of non-typical microbes, potential pathogens, and changes to the diversity of the overall microbiotas and/or the composition and abundance of core bacteria, could be used to monitor health of baleen whales (Apprill et al. 2011, 2014, 2017), including right whales.

To date, samples of blow $(n=120)$ have been collected from NARW and SRW (Argentina, and Auckland Islands, New Zealand) (C. A. Miller et al. unpubl. data). The microbiotas from these blow samples will be explored in the context of body condition measurements, life history traits, and other indices of health. They will also be screened at the genus level for relatives of pathogens and likely will be sequenced deeper to examine the function of the microbes, viruses, and genes involved in virulence. Given the conspicuous differences in body condition between NARW and SRW (Miller et al. 2011, Christiansen et al. 2020), the comparison of the blow-associated microbiotas between these populations has the potential to reveal information about right whale health, in addition to their different habitats and diets.

The gut microbiotas of mammals play an important role in digestion, nutrition, and health. Right whales depend on a diet rich in the high-energy lipids for achieving and sustaining the body fat reserves necessary for reproduction and survival, but little is known about how they digest these lipids because fresh samples of gut contents from right whales are rare. Native Alaskans harvest bowhead Balaena mysticetus whales for subsistence, and in the past, have generously allowed limited access to harvested whales for scientific purposes. Bowhead whales are a close taxonomic relative of right whales and consume prey rich in the same high-energy lipids. Hence, studies of lipid digestion and microbiotas in bowhead whales could provide important information for understanding right whale nutrition. In harvested bowhead whales, lipid digestion and microbial communities were mapped along the gastrointestinal tract (GI, forestomach through colon) by characterizing the lipid compositions (lipidomes) using HPLCMS/MS and the microbiotas using high-throughput sequencing of the V4 region of the 16S rRNA gene (Miller et al. 2020). The lipidomes and microbiotas were tightly correlated as their compositions changed throughout the GI tract, with lipidomes and microbiotas being variable in the small intestine (the area of lipid digestion in mammals). The results suggested that wax esters, the primary prey lipids that are also prominent in right whale prey, were digested in the mid to distal small intestine and that specific bacteria appeared to play a role in their digestion. Despite differences in analytical methods, the bowhead whale gut microbiotas consisted of bacteria from many of the same phyla as Sanders et al. (2015) found in fecal samples from 7 right whales, but direct comparisons of lower level taxonomy are needed. However, because of the similarity in the diets and GI tract anatomy of right and bowhead whales and because they are phylogenetically closely related, these data from (Miller et al. 2020) may provide a model for right whale gut microbiome and lipid digestion, thereby potentially adding to the understanding of right whale nutrition, body condition and overall health.

Additionally, recent analysis of how host phylogeny and life history stage modify the gut microbiome in dwarf Kogia sima and pygmy Kogia breviceps sperm whales (Erwin et al. 2017, Denison et al. 2020) may also have relevance to study of right whale health. 
Overall, skin, blow and gut-associated microbiomes show potential for usefulness in monitoring health of baleen whales-especially blow, which can be collected non-invasively. Paired gut microbiome and lipidome studies have the potential to provide insights into nutrition and body condition and may be useful for evaluating the mechanisms involved in balaenid whale nutrition. Many laboratories are now implementing portable sequencing techniques that could be used to rapidly screen for, and identify, altered microbiomes in field settings (Hu et al. 2018, 2019). This technology has the potential to provide diagnostic-type details about how baleen whale microbiomes change due to animal health and environmental or ecosystem-related alterations.

\subsubsection{Small cetacean health assessments}

Recent advances in small cetacean health assessments are important to review when considering new approaches for evaluating NARW health. In particular, the Deepwater Horizon (DWH) oil spill provided a major opportunity to develop a new synthesis of wild dolphin health assessment tools to better understand the response to a major stressor (Fauquier et al. 2020). These tools allowed for the diagnosis of reproductive failure, lung injury, impaired stress response, and poor body condition in common bottlenose dolphins Tursiops truncatus in the aftermath of the DWH disaster (Schwacke et al. 2014, Lane et al. 2015, Kellar et al. 2017, Smith et al. 2017). Although many of the tools utilized in small cetacean exams would need to be substantially modified for large whales, their potential application to NARW health assessment should be considered (Schwacke et al. 2014, NOAA 2015, Venn-Watson et al. 2015, Smith et al. 2017, Fauquier et al. 2020).

\subsubsection{Predicting Tursiops survival and reproduction from health assessment data}

An expert system developed for predicting survival and reproduction in dolphins based on health assessments could inform approaches for linking current NARW health measures to demography and suggest efficacious future measurements (L. Thomas pers. obs.). The 'Veterinary Expert System for Outcome Prediction' (VESOP) model in dolphins uses statistical models linking measurements of wild bottlenose dolphin health made during hands-on sampling of inshore dolphins with 2-yr-ahead survival and successful reproduction for pregnant females observed by follow-up surveys. Data from 8 populations were included. The numerous measurements of blood and other parameters taken during health assessments have been organized into panels of organ status or specified disease condition to identify abnormal cases for each panel using previously established reference ranges. One future component of the project is to assess how the models and methods developed may be applied to other species for which such comprehensive hands-on health assessments are not available. In particular, if a remote blood sampling device could be developed for large whales, this approach would substantially enhance our understanding of right whale health.

\section{DISCUSSION}

\subsection{NARW health threats}

Understanding NARW health has resulted from decades of research throughout the primary range of this species from Florida to Canada. The sharing and analysis of photographs, samples, and data from both live NARWs and carcasses, has been undertaken by a growing, evolving and integrated community of conservation biologists, modelers, and veterinarians. There is a collaborative ethic, in large part driven by the NARWC being focused on recovery of this endangered species. There is a strong level of collaboration between the USA and Canada at the federal, research and non-governmental organizational levels.

There is a substantial body of information that points to a major impact of lethal and sub-lethal anthropogenic trauma and stressors. However, establishing clear cause and effect linkages can be challenging, especially for the sublethal impacts given that multi-factorial processes are involved.

The key identified species-level concerns are low fecundity resulting in extended inter-birth intervals for some females, and others never calving at all, and poor survival (especially females) from high mortality and chronic morbidity. Together, these are the symptoms of the species downward trajectory. These species-level findings are in stark contrast to the high fecundity and good survival of SRWs. Although SRWs were similarly harvested down to a few hundred animals, in the post-whaling era, the relative lack of anthropogenic threats has allowed the SRW to rebound dramatically. Critical for NARWs is that they 
are exposed to substantially greater human activity than SRW, given that $90 \%$ of the human species lives north of the equator (W. Rankin, The World's Population in 2000 , by Latitude; www.radicalcartography. net/index.html?histpop). This is the fundamental basis for far greater risk of anthropogenic trauma to NARWs.

The primary known stressors for NARWs include food quantity and quality, entanglement, vessel strike, and noise. Climate change-driven distribution shifts of food, followed by the change in distribution of NARWs (Record et al. 2019) have complicated efforts to monitor and manage NARW health by decreasing the ability to document individuals on an annual basis. This requires management measures that are flexible and effective in the face of changing distributions and the uncertainty predicted by climate change. Of these stressors, vessel trauma and entanglement are potentially the most tractable to reduce, in terms of beneficial management actions. Vessel noise is also a serious concern. Fig. 6 summarizes stressors and tools that are important for NARW health studies.

This review identified that the primary tools for assessing individual health include visual health indicators, body condition (an integrated energetic index), presence of vessel strike and entanglement wounds and scars, and detection of biota (biotoxins, parasites, and most recently, microbiome status).
Stress hormones sampled from blow, blubber and feces provide excellent shorter-term indicators of stress. The above tools are primarily collected using boat-based methods. Baleen samples collected at necropsy have provided data on health and nutrition over up to the last $8 \mathrm{yr}$ of an animal's life.

Given the precarious status of the species, the primary roles of existing and potential new health assessment tools are (1) evaluation of the efficacy of management changes designed to enhance species recovery; (2) expansion of our understanding of NARW health and reproductive success; and (3) increased perspective of the relative significance and trends of anthropogenic versus food limitation/other impacts on population health. Central to these goals are models designed to recognize important stressors, responses to them, and to management changes. Table 2 summarizes the available tools for NARW health assessment in the context of each major stressor and their use in assessment of their health and efficacy of mitigation efforts. New and recent tools (Section 2.5 above) may include adaptions for NARW assessments based on those used in the evaluation of the impacts of the DWH spill on small odontocetes (e.g. photo identification, diagnostic pathology and modeling), further development of microbiome studies, possible systems to collect blood samples from large whales at sea, and infra-red thermography from vessels and manned or unmanned aircraft. In

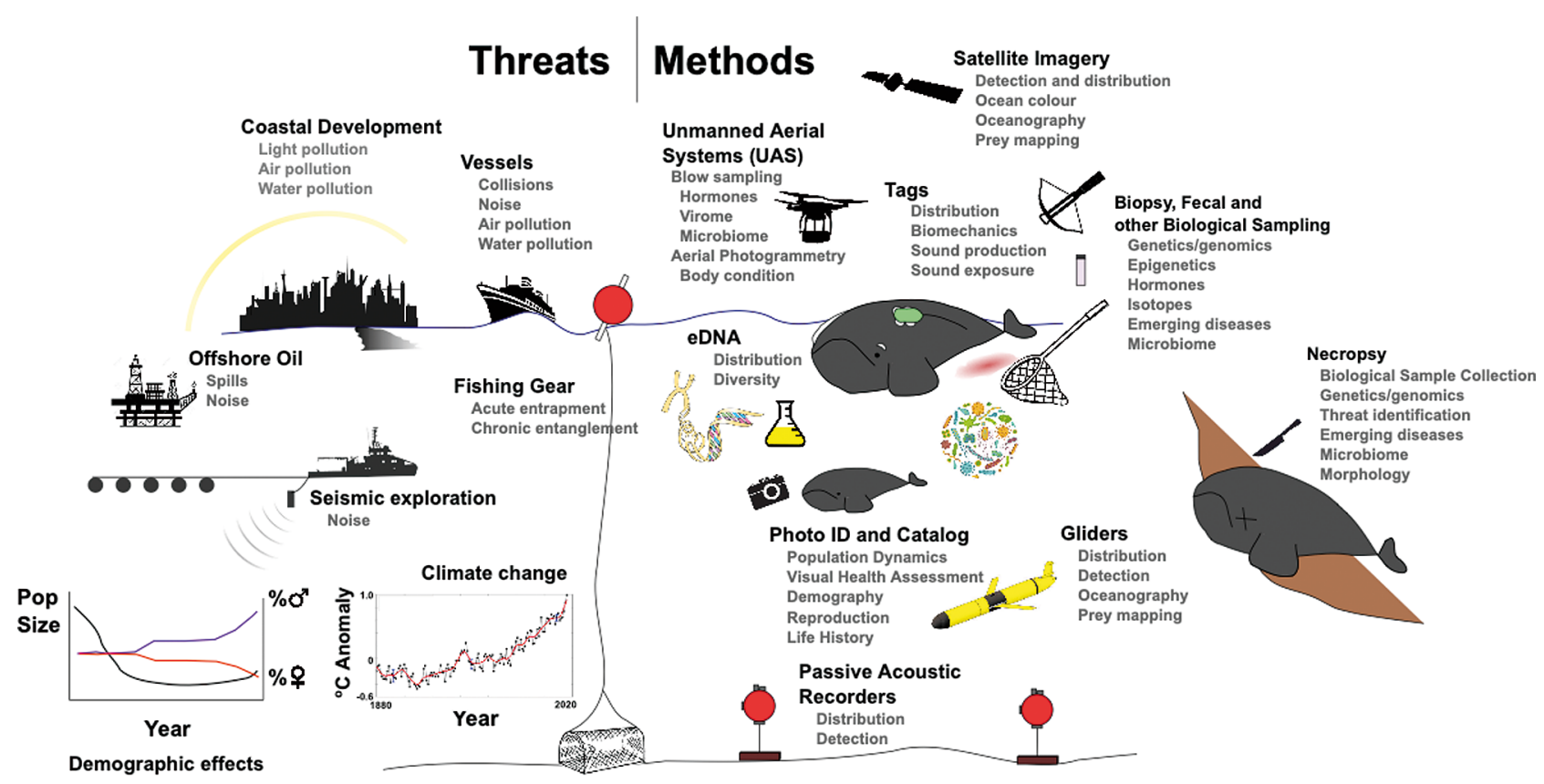

Fig. 6. Summary of the threats facing North Atlantic right whales, and current and potential health assessment methods. Fig. 3 modified from Harcourt et al (2019), with permission from the artist, Julie van der Hoop 


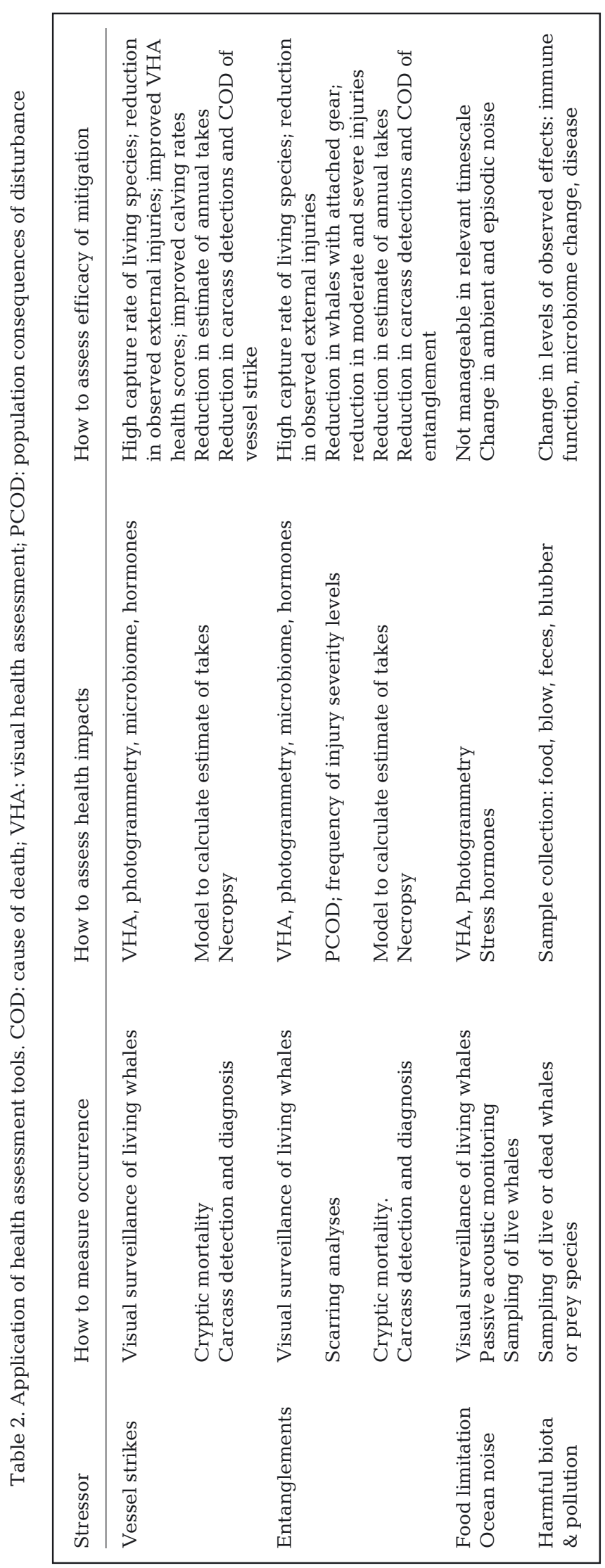

light of the above review, we recommend implementing the following critical measures. Recommendations from the review are collated in Table 3.

\subsection{Population}

(1) Increased shipboard surveys in the recently recognized important NARW habitats are needed to improve our ability to track changes in species status, health, and entanglement or vessel strike wounding/ scarring, as well as to collect biological samples.

(2) Survey efforts need to be flexible to detect future habitat shifts, and survey areas need to be updated. Satellite detection techniques should be employed in this regard as they mature (Bamford et al. 2020) to find new aggregations as possible.

(3) Increased aerial and vessel photographic capture of a larger portion of the species annually is necessary to track individual health and overall species health, as well as allow for continued modeling of vital rates.

(4) Further comparisons between SRW and NARW populations and individuals would potentially add understanding for the failure of the NARW recovery post-whaling.

\subsection{Individual}

(1) Consistent long-term collection of well-calibrated photogrammetric data are needed to provide essential perspectives on changing body condition and growth rates.

(2) Further investigations are needed to detect pregnancy, pregnancy loss, and perinatal loss in the reproductively viable female population. This will inform why fecundity rates are low, and to develop potential remediation actions. Specifically, further investigation is needed to identify the causes for the observed nulliparous females that are old enough to be sexually mature but have not calved.

(3) Increased effort to collect appropriate samples (e.g. biopsy, feces, blow) from adult females without a calf present are needed to allow assessment of pregnancy, pregnancy loss, and resting status through hormonal testing. Exploration into the stage of gestation during which pregnancy loss occurs could potentially be captured through this investigation and be instrumental in the identification of potential stressors that are inducing pregnancy loss. 
Table 3. Summary of information needs and management actions

\begin{tabular}{|c|c|}
\hline Section & Information needs \\
\hline 1 & $\begin{array}{l}\text { Increase the proportion of North Atlantic right whales (NARW) sighted annually, by expanding effort in } \\
\text { current high use habitats such as mid-Atlantic, southern New England, and the Gulf of St Lawrence }\end{array}$ \\
\hline 2.1 & Further compare the demographics of Southern right whales and NARW \\
\hline 2.1 .1 & Diagnostic beach necropsies, and assessment of carcasses at sea as practical \\
\hline 2.1 .2 & $\begin{array}{l}\text { Current Visual Health Assessment of the entire photograph catalog of NARW to qualitatively assess the status } \\
\text { and trends of NARW health }\end{array}$ \\
\hline 2.1 .3 & Method to categorize chronically traumatized whales to better prognosticate \\
\hline 2.1.4.1 & Quantify live animal vessel strike trauma \\
\hline 2.1.4.2 & Quantify live animal entanglement trauma \\
\hline 2.1 .5 & Quantitative assessment of body length and condition changes through time \\
\hline 2.1 .6 & $\begin{array}{l}\text { Establish energetic models involving prey, rope drag, and other sub-lethal trauma to better understand } \\
\text { reproductive failure }\end{array}$ \\
\hline 2.1 .7 & Acute and chronic effects of background and episodic noise trauma \\
\hline 2.2 .1 & Assessment of relationship of sub-lethal trauma to reproductive success \\
\hline 2.2 .1 & SRW vs. NARW foraging dynamics \\
\hline 2.2 .1 & Surface active group prevalence vs. calving rate by habitat \\
\hline 2.2 .2 & Endocrine basis of pregnancy and recruitment success, and stress response \\
\hline 2.3 & Comparison of biotoxin exposure and effects in SRW and NARW \\
\hline 2.3 & $\begin{array}{l}\text { Giardia and Cryptosporidium vs. decline in body condition, including genotyping and tracking origin of } \\
\text { infections }\end{array}$ \\
\hline 2.4 & Survival, demographic and multiple stressor models \\
\hline 2.5 .1 & Microbiomes in the context of health and disease \\
\hline 2.5.3 & Develop a large whale blood sampling tool \\
\hline Section & Management actions for conservation merit \\
\hline 2.1 .1 & Use diagnostic necropsy data to evaluate effectiveness of NARW trauma mitigation strategies \\
\hline 2.1.4.1 & Substantially reduce large vessel propeller trauma \\
\hline 2.1.4.2 & Consider maximum rope strength of $1700 \mathrm{lb}(\sim 773 \mathrm{~kg})$ throughout NARW range \\
\hline 2.1.4.3 & Minimize sub-lethal vessel and entanglement trauma \\
\hline 2.1 .6 & Removal of rope from the water column to reduce trauma and energy loss in sub-lethal entanglements \\
\hline 2.1.7 & Reduce background and episodic noise \\
\hline 2.2 .1 & Minimize sub-lethal and lethal trauma to enable NARW recovery \\
\hline
\end{tabular}

(4) Analysis of fecal, blow, and biopsy samples for microbiome and other biota are needed to enhance our understanding of overall health in this species.

(5) Greater capacity to retrieve and examine floating carcasses from substantial offshore distances to enhance evaluation of mitigation efforts.

\subsection{Modeling}

(1) An assessment of the interaction of multiple stressors in each major habitat is needed to enable more spatially precise management measures and to improve modeling efforts to determine how broad scale management measures may influence health and reproduction (Fig. 7).

(2) Population consequence of multiple stressor (PCOMS) and other models are needed to test the conservation and species recovery benefit of undertaking specific health assessment options.

\subsection{Management}

(1) Shifting mortality locations indicate the need for effective broad-scale management measures that allow healthy female NARWs to forage, conceive, deliver, and wean calves.

(2) Management needs are summarized in Table 3.

\section{CONCLUSIONS}

In contrast to SRW, the NARW species has failed to maintain a positive trajectory towards recovery from the impacts of historic whaling. The reasons for this are complex but center on the far greater pressure from human activities in the northern versus southern hemispheres.

The major known anthropogenic sources of lethal and sublethal NARW trauma are from collisions with vessels and fishing gear entanglement. These have 


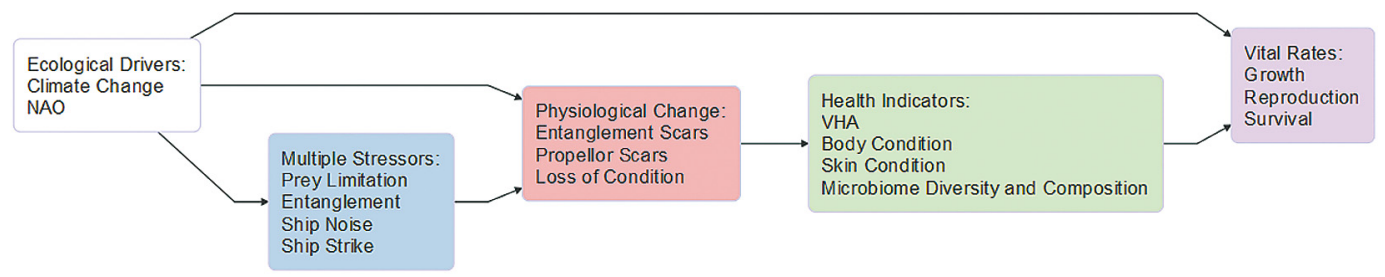

Fig. 7. Population consequence of multiple stressors conceptual model for North Atlantic right whales that links multiple stressors (blue box) to changes in physiology, trauma and condition (red box) that are detected from retrospective and drone-based studies (green box). All of these, as well as background environmental signals of climate change and the North Atlantic Oscillation (NAO), link to changes in growth (measured by drone photogrammetry), reproduction and survival (purple box). VHA: visual health assessment

increased in recent decades. Vessels have got larger and faster, increasing the lethality and frequency of collisions. Fishing gear strength has increased, with resultant increased morbidity and mortality from entanglement.

The already poor fecundity and survival of NARWs has devolved into a recent decline. The species peaked at 500 individuals in 2010. The best estimate for 2019 is approximately 360 animals.

Climate-driven changes in NARW habitat features (biological, physical, chemical) resulting in changes in migration and foraging patterns that have correlated with a further reduction in already poor reproductive success. Extreme recent warming of the Gulf of Maine, a major feeding habitat, has led to an increase in the use of the Gulf of St Lawrence, when ice free.

The interaction of sub-lethal stressors such as decreased energy intake and entanglement trauma must be better quantified in order to identify critical management strategies to enhance NARW body condition and reproductive success. While foraging success is the most critical determinant of health, little can be done to enhance it, whereas anthropogenic trauma is also a major factor and is avoidable, given adequate and effective management changes.

Tools critical to assessing the efficacy of measures to mitigate failed recovery include visual surveys, photo-ID catalog-based species analyses, annual scarring assessments, visual and photogrammetric health assessments, and necropsies. These efforts are ongoing but need to be continually optimized as environmental changes drive shifts in NARW distribution and behavior.

Investigation of individual health, analyzing blow, blubber, fecal, and other samples in addition to conducting complete necropsy examinations is critical to better understanding the health, reproductive status, and disease states of the NARW population. While we understand the fundamental role of trauma in NARW status, a more nuanced under- standing of other aspects of their health would be hugely valuable.

Modeling is critical to our understanding of the status and trends of NARW health, and in particular for understanding the interactions of multiple stressors on both individuals and the species as a whole. Given the fragmented and changing nature of routine sighting and health assessment opportunities, models are critical to translate available data into best estimates of NARW status and trends.

Acknowledgements. This review summarizes material presented and discussed at a workshop on North Atlantic Right Whale Health Assessment, June 24-26, 2019, Silver Spring MD, USA (Fauquier et al. 2020). We thank all the participants of the workshop for their contributions. NA14OAR4320158 funded the drafting of this manuscript. We sincerely thank 3 anonymous reviewers for their constructive comments. The scientific results and conclusions, as well as any views or opinions expressed herein, are those of the authors and do not necessarily reflect the views of NOAA.

\section{LITERATURE CITED}

Apprill A, Mooney TA, Lyman E, Stimpert AK, Rappé MS (2011) Humpback whales harbour a combination of specific and variable skin bacteria. Environ Microbiol Rep 3: 223-232

Apprill A, Robbins J, Eren AM, Pack AA and others (2014) Humpback whale populations share a core skin bacterial community: Towards a health index for marine mammals? PLOS ONE 9:e90785

Apprill A, Miller C, Moore M, Durban J, Fearnbach H, Barrett-Lennard L (2017) Extensive core microbiome in drone-captured whale blow supports a framework for health monitoring. mSystems 2:e00119-e17

Apprill A, Miller CA, Van Cise AM, U'Ren JM, Leslie MS, Weber L and others (2020) Marine mammal skin microbiotas are influenced by host phylogeny. R Soc Open Sci 7:192046

Bamford CCG, Kelly N, Dalla Rosa L, Cade DE and others (2020) A comparison of baleen whale density estimates derived from overlapping satellite imagery and a shipborne survey. Sci Rep 10:12985

Best PB, Bannister JL, Brownell RL, Donovan GP (eds) (2001) Right whales: worldwide status. J Cetacean Res Manag Spec Issue 2:1-309 
Bierlich KC, Miller C, DeForce E, Friedlaender AS, Johnston DW, Apprill A (2018) Temporal and regional variability in the skin microbiome of humpback whales along the Western Antarctic Peninsula. Appl Environ Microbiol 84: e02574-17

Bik EM, Costello EK, Switzer AD, Callahan BJ and others (2016) Marine mammals harbor unique microbiotas shaped by and yet distinct from the sea. Nat Commun 7: 10516

Bourque L, Wimmer T, Lair S, Jones M, Daoust PY (2020) Incident report: North Atlantic right whale mortality event in eastern Canada, 2019. Collaborative report produced by: Canadian Wildlife Health Cooperative and Marine Animal Response Society. http://cwhc-rcsf.ca/ docs $/ 2019 \% 20$ NARW\%20incident $\% 20$ report_June $\%$ 202020.pdf

Brownell R, Best P, Prescott J (1986) Right whales: past and present status. Rep Int Whal Comm Spec Issue 10: 1-289

Burgess EA, Hunt KE, Kraus SD, Rolland RM (2017) Adrenal responses of large whales: integrating fecal aldosterone as a complementary biomarker to glucocorticoids. Gen Comp Endocrinol 252:103-110

Cho I, Blaser MJ (2012) The human microbiome: at the interface of health and disease. Nat Rev Genet 13:260-270

Christiansen F, Vivier F, Charlton C, Ward R, Amerson A, Burnell S, Bejder L (2018) Maternal body size and condition determine calf growth rates in southern right whales. Mar Ecol Prog Ser 592:267-281

Christiansen F, Dawson SM, Durban JW, Fearnbach H and others (2020) Population comparison of right whale body condition reveals poor state of the North Atlantic right whale. Mar Ecol Prog Ser 640:1-16

Cooke JG (2020) Eubalaena glacialis. The IUCN Red List of Threatened Species 2020: e.T41712A162001243 (accessed 09 July 2020). www.iucnredlist.org/species/41712/ 162001243

Corkeron P, Hamilton P, Bannister J, Best P and others (2018) The recovery of North Atlantic right whales, Eubalaena glacialis, has been constrained by humancaused mortality. R Soc Open Sci 5:180892

Daoust PY, Coutoure E, Wimmer T, Bourque L (2018) Incident report: North Atlantic right whale mortality event in the Gulf of St. Lawrence, 2017. Collaborative report produced by Canadian Wildlife Health Cooperative, Marine Animal Response Society, and Fisheries and Oceans Canada. www.cwhc-rcsf.ca/docs/technical_reports/NARW_ Incident_Report-\%2020180405\%20MD.pdf

Davies KTA, Brown MW, Hamilton PK, Knowlton AR, Taggart CT, Vanderlaan ASM (2019) Variation in North Atlantic right whale Eubalaena glacialis occurrence in the Bay of Fundy, Canada, over three decades. Endang Species Res 39:159-171

Davis GE, Baumgartner MF, Bonnell JM, Bell J and others (2017) Long-term passive acoustic recordings track the changing distribution of North Atlantic right whales (Eubalaena glacialis) from 2004 to 2014. Sci Rep 7: 13460

Denison ER, Rhodes RG, McLellan WA, Pabst DA, Erwin PM (2020) Host phylogeny and life history stage shape the gut microbiome in dwarf (Kogia sima) and pygmy (Kogia breviceps) sperm whales. Sci Rep10:15162

Doucette GJ, Mikulski CM, King KL, Roth PB and others (2012) Endangered North Atlantic right whales (Eubalaena glacialis) experience repeated, concurrent expo- sure to multiple environmental neurotoxins produced by marine algae. Environ Res 112:67-76

* Durban JW, Moore MJ, Chiang G, Hickmott LS and others (2016) Photogrammetry of blue whales with an unmanned hexacopter. Mar Mamm Sci 32:1510-1515

Erwin PM, Rhodes RG, Kiser KB, Keenan-Bateman TF, McLellan WA, Pabst DA (2017) High diversity and unique composition of gut microbiomes in pygmy (Kogia breviceps) and dwarf (K. sima) sperm whales. Sci Rep 7:7205

*Ezenwa VO, Gerardo NM, Inouye DW, Medina M, Xavier JB (2012) Animal behavior and the microbiome. Science 338:198-199

Fauquier D, Long K, Biedron I, Wilkin S and others (2020) Report of the Health Assessment Workshop for North Atlantic Right Whales (Eubalaena glacialis), June 24-26, 2019. NOAA Tech Memo NMFS-F/OPR-65. https:// repository.library.noaa.gov/view/noaa/27432

* Gowan TA, Ortega-Ortiz JG, Hostetler JA, Hamilton PK and others (2019) Temporal and demographic variation in partial migration of the North Atlantic right whale. Sci Rep 9:353

* Hamilton PK, Cooper LA (2010) Changes in North Atlantic right whale (Eubalaena glacialis) cow-calf association times and use of the calving ground: 1993-2005. Mar Mamm Sci 26:896-916

*Hamilton PK, Marx MK (2005) Skin lesions on North Atlantic right whales: categories, prevalence and change in occurrence in the 1990s. Dis Aquat Org 68:71-82

Hamilton PK, Knowlton AR, Marx MK, Kraus SD (1998) Age structure and longevity in North Atlantic right whales Eubalaena glacialis and their relation to reproduction. Mar Ecol Prog Ser 171:285-292

Hamilton P, Knowlton A, Marx M (2007) Right whales tell their own stories: the photo-identification catalog. In: Kraus S, Rolland R (eds) The urban whale: North Atlantic right whales at the crossroads. Harvard University Press, Cambridge, MA, p 75-104

*Harcourt R, van der Hoop J, Kraus S, Carroll EL (2019) Future directions in Eubalaena spp.: comparative research to inform conservation. Front Mar Sci 5:530

* Hlista BL, Sosik HM, Martin Traykovski LV, Kenney RD, Moore MJ (2009) Seasonal and inter-annual correlations between right-whale distribution and calving success and chlorophyll concentrations in the Gulf of Maine, USA. Mar Ecol Prog Ser 394:289-302

* Hu YO, Ndegwa N, Alneberg J, Johansson S and others (2018) Stationary and portable sequencing-based approaches for tracing wastewater contamination in urban stormwater systems. Sci Rep 8:11907

$\mathrm{Hu}$ Y, Green GS, Milgate AW, Stone EA, Rathjen JP, Schwessinger B (2019) Pathogen detection and microbiome analysis of infected wheat using a portable DNA sequencer. Phytobiomes J 3:92-101

*Hughes-Hanks JM, Rickard LG, Panuska C, Saucier JR, O'Hara TM, Dehn L, Rolland RM (2005) Prevalence of Cryptosporidium spp. and Giardia spp. in five marine mammal species. J Parasitol 91:1225-1228

*Hunt KE, Rolland RA, Kraus SD, Wasser SK (2006) Analysis of fecal glucocorticoids in the North Atlantic right whale (Eubalaena glacialis). Gen Comp Endocrinol 148: 260-272

Hunt KE, Lysiak NS, Moore MJ, Rolland RM (2016) Longitudinal progesterone profiles in baleen from female North Atlantic right whales (Eubalaena glacialis) match known calving history. Conserv Physiol 4:cow014 
International Whaling Commission (2010) Report of the Southern Right Whale Die-Off Workshop 15-18 March 2010, Centro Nacional Patagónico, Puerto Madryn, Argentina SC/62/Rep1

International Whaling Commission (2013) Report of the Southern Right Whale die-off workshop. J Cetacean Res Manag 12: 367-398

Jackson JA, Kennedy A, Moore M, Andriolo A and others (2020) Have whales returned to a historical hotspot of industrial whaling? The pattern of southern right whale Eubalaena australis recovery at South Georgia. Endang Species Res 43:323-339

Kellar NM, Speakman TR, Smith CR, Lane SM and others (2017) Low reproductive success rates of common bottlenose dolphins Tursiops truncatus in the northern Gulf of Mexico following the Deepwater Horizon disaster (2010-2015). Endang Species Res 33:143-158

Kemper C, Coughran D, Warneke R, Pirzl R, Watson M, Gales R, Gibbs S (2008) Southern right whale (Eubalaena australis) mortalities and human interactions in Australia, 1950-2006. J Cetacean Res Manag 10:1-8

Kenney RD, Mayo CA, Winn HE (2020) Migration and foraging strategies at varying spatial scales in western North Atlantic right whales: a review of hypotheses. J Cetacean Res Manag Spec Issue 2:251-260

Knowlton A, Kraus S, Kenney R (1994) Reproduction in North Atlantic right whales (Eubalaena glacialis). Can J Zool 72:1297-1305

Knowlton AR, Hamilton PK, Marx MK, Pettis HM Kraus SD (2012) Monitoring North Atlantic right whale Eubalaena glacialis entanglement rates: a $30 \mathrm{yr}$ retrospective. Mar Ecol Prog Ser 466:293-302

Knowlton AR, Robbins J, Landry S, McKenna HA, Kraus SD, Werner TB (2016) Effects of fishing rope strength on the severity of large whale entanglements. Conserv Biol 30: 318-328

Kraus SD (1990) Rates and potential causes of mortality in the north Atlantic right whales (Eubalaena glacialis). Mar Mamm Sci 6:278-291

Kraus SD, Prescott JH, Knowlton AR, Stone GS (1986) Migration and calving of right whales (Eubalaena glacialis) in the western North Atlantic. Rep Int Whal Comm (Spec Issue) 10:139-144

Laist DW, Knowlton AR, Pendleton D (2014) Effectiveness of mandatory vessel speed limits for protecting North Atlantic right whales. Endang Species Res 23:133-147

Lane SM, Smith CR, Mitchell J, Balmer BC and others (2015) Reproductive outcome and survival of common bottlenose dolphins sampled in Barataria Bay, Louisiana, USA, following the Deepwater Horizon oil spill. Proc Proc R Soc B 282:20151944

K Leaper R, Cooke J, Trathan P, Reid K, Rowntree V, Payne $R$ (2006) Global climate drives southern right whale (Eubalaena australis) population dynamics. Biol Lett 2: 289-292

Ley RE (2010) Obesity and the human microbiome. Curr Opin Gastroenterol 26:5-11

Lysiak NSJ, Trumble SJ, Knowlton AR, Moore MJ (2018) Characterizing the duration and severity of fishing gear entanglement on a North Atlantic right whale (Eubalaena glacialis) using stable isotopes, steroid and thyroid hormones in Baleen. Front Mar Sci 5:168

Maul GE, Sergeant DE (1977) New Cetacean records from Madeira. Bocagiana. 43:1-8. http://publications.cmfunchal.pt/jspui/handle/100/1521
McFall-Ngai M, Hadfield MG, Bosch TC, Carey HV and others (2013) Animals in a bacterial world, a new imperative for the life sciences. Proc Natl Acad Sci USA 110: 3229-3236

* Meyer-Gutbrod EL, Greene CH, Sullivan PJ, Pershing AJ (2015) Climate-associated changes in prey availability drive reproductive dynamics of the North Atlantic right whale population. Mar Ecol Prog Ser 535:243-258

Miller CA, Reeb D, Best PB, Knowlton AR, Brown MW, Moore MJ (2011) Blubber thickness in right whales Eubalaena glacialis and Eubalaena australis related with reproduction, life history status and prey abundance. Mar Ecol Prog Ser 438:267-283

* Miller CA, Holm HC, Horstmann L, George JC, Fredricks HF, Van Mooy BA, Apprill A (2020) Coordinated transformation of the gut microbiome and lipidome of bowhead whales provides novel insights into digestion. ISME J 14:688-701

Moore M, Myers H (2019) High-tech fishing gear could help save critically endangered right whales. https://theconversation.com/high-tech-fishing-gear-could-help-savecritically-endangered-right-whales-115974

Moore M, Knowlton A, Kraus S, McLellan W, Bonde R (2004) Morphometry, gross morphology and available histopathology in Northwest Atlantic right whale (Eubalaena glacialis) mortalities (1970 to 2002). J Cetacean Res Manag 6:199-214

* Moore MJ, Mitchell GH, Rowles TK, Early G (2020) Dead Cetacean? Beach, bloat, float, sink. Front Mar Sci 7:333

*Nelson TM, Apprill A, Mann J, Rogers TL, Brown MV (2015) The marine mammal microbiome: current knowledge and future directions. Microbiol Aust 36:8-13

NOAA (2012) Process for injury determination distinguishing serious from non-serious injury of marine mammals. www.fisheries.noaa.gov/webdam/download/ 64668196

NOAA (2015) Injury to natural resources. In: Deepwater Horizon oil spill: draft programmatic damage assessment and restoration plan and draft programmatic environmental impact statement, National Oceanic and Atmospheric Administration. www.gulfspillrestoration.noaa. gov/wp-content/uploads/Chapter-4_Injury-to-NaturalResources1.pdf (accessed 11 Nov 2015)

NOAA (2020) North Atlatnic right whale stock assessment reports. www.fisheries.noaa.gov/national/marine-mammal-protection/marine-mammal-stock-assessments

O'Hara T, Rolland R, Reeves R (2003) Report from Bowhead/ Right Whale Comparative Health and Physiology Workshop, March 25-26, 2003. https://repository.library.noaa. gov/view/noaa/23704.1-30

Pace RM, Corkeron PJ, Kraus SD (2017) State-space markrecapture estimates reveal a recent decline in abundance of North Atlantic right whales. Ecol Evol 7:8730-8741

* Pace RM, Williams R, Kraus SD, Knowlton AR, Pettis HM (2021) Cryptic mortality in North Atlantic right whales. Conserv Sci Pract 3:e346

Parks SE, Clark CW, Tyack PL (2007) Short- and long-term changes in right whale calling behavior: the potential effects of noise on acoustic communication. J Acoust Soc Am 122:3725-3731

Payne R, Brazier O, Dorsey EM, Perkins JS, Rowntree VJ, Titus A (1983) External features in southern right whales (Eubalaena australis) and their use in identifying individuals. In: Payne R (ed) Communication and behavior of whales. Westview Press, Boulder, CO, p 371-445 
Pershing AJ, Record NR, Monger BC, Mayo CA and others (2009) Model-based estimates of right whale habitat use in the Gulf of Maine. Mar Ecol Prog Ser 378:245-257

Pettis HM (2019) Final report on right whale visual health assessment. In: Hamilton PK, Knowlton AR, Hagbloom $\mathrm{MN}$, Howe KR and others (eds) Maintenance of the North Atlantic right whale catalog, whale scarring and visual health databases, anthropogenic injury case studies, and near real-time matching for biopsy efforts, entangled, injured, sick, or dead right whales. Contract No. 1305M2-18-PNFFM-0108. Report to National Marine Fisheries Service, Woods Hole, MA, p 97-105

Pettis H, Rolland R, Hamilton P, Knowlton A, Kraus S, Brault S (2004) Visual health assessment of North Atlantic right whales (Eubalaena glacialis) using photographs. Can J Zool 82:8-19

Pettis H, Pace R, Hamilton P (2020) North Atlantic Right Whale Consortium 2019 Annual Report Card. www. narwc.org/report-cards.html

*Pirotta V, Smith A, Ostrowski M, Russell D, Jonsen ID, Grech A, Harcourt R (2017) An economical custom-built drone for assessing whale health. Front Mar Sci 4:425

* Plourde S, Lehoux C, Johnson CL, Perrin G, Lesage V (2019) North Atlantic right whale (Eubalaena glacialis) and its food: (I) a spatial climatology of Calanus biomass and potential foraging habitats in Canadian waters. J Plankton Res 41:667-685

Record N, Runge J, Pendleton D, Balch W and others (2019) Rapid climate-driven circulation changes threaten conservation of endangered North Atlantic right whales. Oceanography (Wash DC) 32:162-169

Reeves RR, Rolland R, Clapham PJ (2001) Causes of reproductive failure in North Atlantic right whales: new avenues of research. NEFSC Ref Doc 01-16:1-46

Reeves R, Smith T, Josephson E (2007) Near-annihilation of a species: right whaling in the North Atlantic. In: Kraus S, Rolland R (eds) The urban whale: North Atlantic right whales at the crossroads. Harvard University Press, Cambridge, MA, p 39-74

Rolland R, Moore M (2018) Health assessment of large whales. In: Gulland G, Dierauf L, Whitman K (eds) Marine mammal medicine. Taylor and Francis, Boca Raton, FL, p 835-848

Rolland RM, Hunt KE, Kraus SD, Wasser SK (2005) Assessing reproductive status of right whales (Eubalaena glacialis) using fecal hormone metabolites. Gen Comp Endocrinol 142:308-317

Rolland R, Hunt K, Doucette G, Rickard L, Wasser S, Kraus S, Rolland R (2007) The inner whale: hormones, biotoxins and parasites. In: Kraus S, Rolland R (eds) The urban whale: North Atlantic right whales at the crossroads. Harvard University Press, Cambridge, MA, p 232-272

Rolland RM, Parks SE, Hunt KE, Castellote M and others (2012) Evidence that ship noise increases stress in right whales. Proc R Soc B Biol Sci 279:1737

Rolland RM, Schick RS, Pettis HM, Knowlton AR, Hamilton PK, Clark JS, Kraus SD (2016) Health of North Atlantic right whales Eubalaena glacialis over three decades: from individual health to demographic and population health trends. Mar Ecol Prog Ser 542:265-282

Rolland RM, McLellan WA, Moore MJ, Harms CA, Burgess EA, Hunt KE (2017) Fecal glucocorticoids and anthropogenic injury and mortality in North Atlantic right whales Eubalaena glacialis. Endang Species Res 34: $417-429$
Rowles T, Bradford A, Calambokidis J, Falcone E and others (2006) Draft report of the NOAA Large Whale Health Assessment Workshop held in Olympia, Washington on 8-9 December 2006. Report SC/59/DW2. International Whaling Commission Cambridge, p 1-7

Sanders JG, Beichman AC, Roman J, Scott JJ, Emerson D, McCarthy JJ, Girguis PR (2015) Baleen whales host a unique gut microbiome with similarities to both carnivores and herbivores. Nat Commun 6:8285

* Schick RS, Kraus SD, Rolland RM, Knowlton AR and others (2013) Using hierarchical Bayes to understand movement, health, and survival in the endangered North Atlantic right whale. PLOS ONE 8:e64166

Schick RS, Kraus SD, Rolland RM, Knowlton AR and others (2016) Effects of model formulation on estimates of health in individual right whales (Eubalaena glacialis). In: Popper AN, Hawkins A (eds), The effects of noise on aquatic life II. Springer, Berlin, p 977-985

Schwacke LH, Smith CR, Townsend FI, Wells RS and others (2014) Health of common bottlenose dolphins (Tursiops truncatus) in Barataria Bay, Louisiana, following the Deepwater Horizon oil spill. Environ Sci Technol 48: 93-103

Seyboth E, Groch KR, Dalla Rosa L, Reid K, Flores PA, Secchi ER (2016) Southern right whale (Eubalaena australis) reproductive success is influenced by krill (Euphausia superba) density and climate. Sci Rep 6:28205

Sharp SM, McLellan WA, Rotstein DS, Costidis AM and others (2019) Gross and histopathologic diagnoses from North Atlantic right whale Eubalaena glacialis mortalities between 2003 and 2018. Dis Aquat Org 135:1-31

* Silber GK, Adams JD, Fonnesbeck CJ (2014) Compliance with vessel speed restrictions to protect North Atlantic right whales. PeerJ 2:e399

* Sironi M, Rowntree VJ, Di Martino M, Beltramino L, Rago V, Marón C, Uhart M (2018) Southern right whale mortalities at Península Valdés, Argentina: updated information for 2016-2017. Report SC/67B/CMP/06. International Whaling Commission, Cambridge

Sisson N, Long K (2018) Evaluating effectiveness of U.S. management measures for North Atlantic right whales, Summary of an Expert Working Group Meeting. https:// repository.library.noaa.gov/view/noaa/23429 Pages:1-23

Smith CR, Rowles TK, Hart LB, Townsend FI and others (2017) Slow recovery of Barataria Bay dolphin health following the Deepwater Horizon oil spill (2013-2014), with evidence of persistent lung disease and impaired stress response. Endang Species Res 33:127-142

Stamation K, Watson M, Moloney P, Charlton C, Bannister J (2020) Population estimate and rate of increase of southern right whales Eubalaena australis in southeastern Australia. Endang Species Res 41:373-383

Stephen C (2014) Toward a modernized definition of wildlife health. J Wildl Dis 50:427-430

* Tennessen JB, Parks SE (2016) Acoustic propagation modeling indicates vocal compensation in noise improves communication range for North Atlantic right whales. Endang Species Res 30:225-237

Thomas PT, Uhart M, McAloose D, Sironi M and others (2013) Workshop on the southern right whale die-off at Península Valdés, Argentina. Report SC/65a/BRG15. Interantional Whaling Commission, Cambridge

*van der Hoop J, Moore M, Barco S, Cole T and others (2013) Assessment of management to mitigate anthropogenic effects on large whales. Conserv Biol 27:121-133 
van der Hoop JM, Vanderlaan ASM, Cole TVN, Henry AG and others (2014) Vessel strikes to large whales before and after the 2008 Ship Strike Rule. Conserv Lett 8: 24-32

van der Hoop JM, Corkeron P, Kenney J, Landry S, Morin D, Smith J, Moore MJ (2016) Drag from fishing gear entangling North Atlantic right whales. Mar Mamm Sci 32: 619-642

van der Hoop J, Corkeron P, Moore M (2017a) Entanglement is a costly life-history stage in large whales. Ecol Evol 7: 92-106

van der Hoop JM, Nowacek DP, Moore MJ, Triantafyllou MS (2017b) Swimming kinematics and efficiency of entangled North Atlantic right whales. Endang Species Res 32:1-17

Van Waerebeek K, Baker AN, Felix F, Gedamke J and others (2007) Vessel collisions with small cetaceans world-

Editorial responsibility: Dave S. Rotstein,

Olney, Maryland, USA wide and with large whales in the Southern Hemisphere, an initial assessment. Lat Am J Aquat Mamm 6:43-69

*Venn-Watson S, Colegrove KM, Litz J, Kinsel M and others (2015) Adrenal gland and lung lesions in Gulf of Mexico common bottlenose dolphins (Tursiops truncatus) found dead following the Deepwater Horizon oil spill. PLOS ONE 10:e0126538

* Wilson C, Sastre AV, Hoffmeyer M, Rowntree VJ and others (2016) Southern right whale (Eubalaena australis) calf mortality at Península Valdés, Argentina: Are harmful algal blooms to blame? Mar Mamm Sci 32:423-451

Yablokov AV (1994) Validity of whaling data. Nature 367: 108

Kappes CA, da Silva CV, Pontalti M, Danielski ML, Di Beneditto APM (2013) The conflict between the southern right whale and coastal fisheries on the southern coast of Brazil. Mar Policy 38:428-437

Submitted: September 25, 2020; Accepted: January 6, 2021 Proofs received from author(s): February 22, 2021 